\title{
AVALIAÇÃO DE CARAMBOLA (Averrhoa carambola L.) DOS TIPOS DOCE E ÁCIDO, PARA O PROCESSAMENTO DE FRUTA EM CALDA
}

\section{PATRICIA PRATI}

Engenheira Agrônoma

Orientador: Prof. Dr. JOĀO NUNES NOGUEIRA

Dissertação apresentada à Escola Superior de Agricultura "Luiz de Queirßz", Universidade de Săo Paulo, para obtenção do título de Mestre em Agronomia, Área de Concentração:Ciência e Tecnologia de Alimentos.

\author{
PIRACICABA \\ Estado de São Paulo - Brasil
}

Novembro - 1999 


\title{
Dados Internacionais de Catalogaçāo na Publicaçāo (CIP) DIVISĀO DE BIBLIOTECA E DOCUMENTAÇĀO - Campus "Luiz de Queiroz"/USP
}

\author{
Prati, Patricia \\ Avaliação de carambola (Averthoa carambola L.) dos tipos doce e ácido, para o \\ processamento de fruta em calda / Patricia Prati. - - Piracicaba, 1999. \\ $65 \mathrm{p}$. \\ Dissertação (mestrado) - - Escola Superior de Agricultura Luiz de Queiroz, 1999. \\ Bibliografia \\ 1. Carambola 2.Doce de fruta 3. Fruta em calda 4 . Tecnologia de alimento 1 . \\ Titulo
}

$$
\text { CDD } 664.80 \% 6
$$

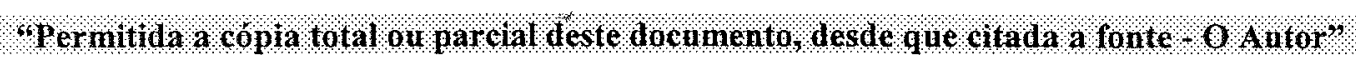


A Deus agradeço.

Aos meus pais que sempre me apoiaram e orientaram em todas as decisões da minha vida, À minha irmã Mariana pela colaboração e apoio, Ao Ademir pela colaboração, compreensão e respeito à minha vida profissional, dedico este trabalho. 


\section{AGRADECIMENTOS}

- Ao Prof. Dr. João Nunes Nogueira, pela orientação e colaboração na realização deste trabalho.

- Aos professores do Curso de Mestrado, pelos ensinamentos e pelo apoio.

- Ao Prof. Dr. Carlos Tadeu dos Santos Dias (Departamento de Estatística), pelo auxílio prestado na análise estatística.

- Ao Engenheiro Agrônomo Paulo Sérgio de Araújo, pelo auxílio na obtenção da matéria-prima.

- Ao Sítio Shimazaki, pelo fornecimento da matéria-prima.

- Às bibliotecárias, Midiam Gustinelli e Beatriz Helena Giongo, pela amizade e pelo auxílio na revisão e obtenção das referências bibliográficas deste trabalho.

- Em especial, às técnicas Ivani Aparecida Marchetto Moreno, Juliana Antunes Galvão e Roberta Teresa Rizzo Benato, pela amizade, orientação e pelo auxílio prestado na elaboração da parte prática do trabalho.

- Aos membros do painel sensorial, pela colaboração e compreensão.

- A todos os funcionários do Departamento de Agroindústria, Alimentos e Nutrição, pela amizade.

- À Mariana e Ademir, pelo auxílio prestado na elaboração da parte prática do trabalho.

- À Engenheira Agrônoma Marilisa Flavia Di-Tanno, pela amizade, apoio e incentivo. 


\section{SUMÁRIO}

Página

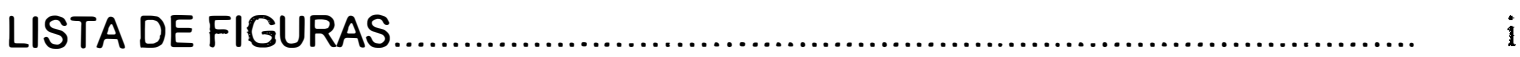

LISTA DE TABELAS ................................................................................ ii

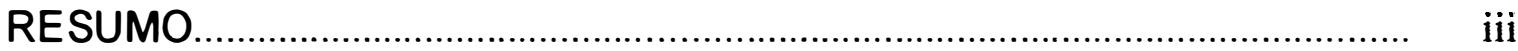

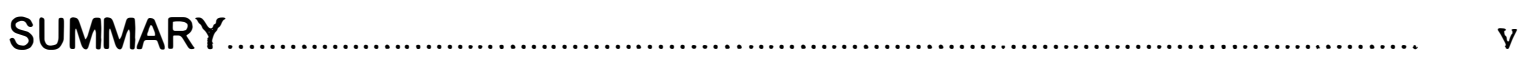

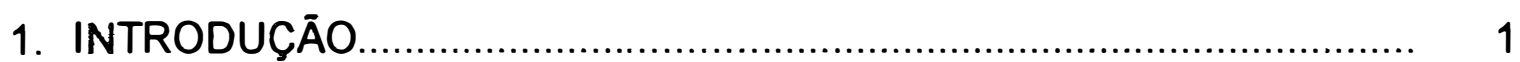

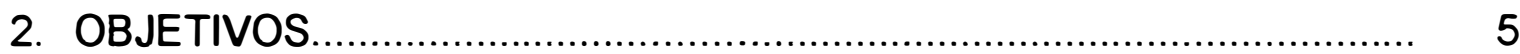

3. REVISĀO DE LITERATURA........................................................... 6

3.1. Considerações gerais....................................................................... 6

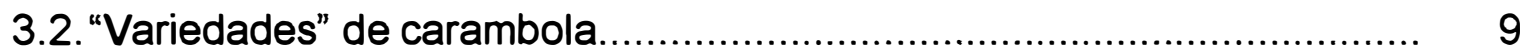

3.3. Fatores que afetam a qualidade da carambola.................................... 9

3.3.1. Características das frutas.......................................................... 9

3.3.2. Ação das enzimas................................................................ 12

3.3.3. Alterações de pigmentos........................................................... 15

3.3.4. Alterações na textura.................................................................... 17

3.3.5. Outros fatores importantes.................................................... 19

3.3.6. Aplicação do calor........................................................................ 21

3.3.7. Processamento de carambola...................................................... 24

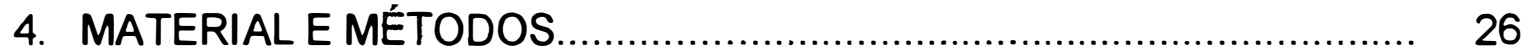

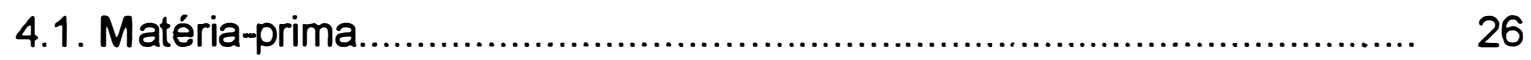

4.2. Características da matéria-prima.................................................... 26

4.2.1. Análises físicas........................................................................ 26

4.2.2. Análises químicas..................................................................... 27

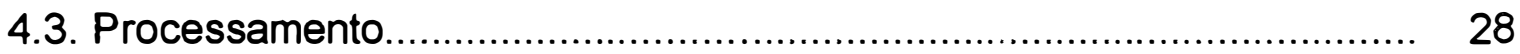

4.3.1. Tratamentos de pré-processamento............................................... 28

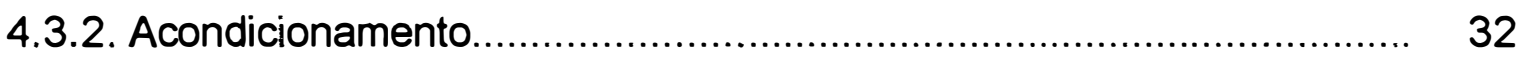

4.3.3. Exaustão e recravação................................................................. 32

4.3.4. Esterilização e resfriamento....................................................... 32

4.3.5. Armazenamento...................................................................... 32 
4.4. Avaliaçāo do produto processado...................................................... 32

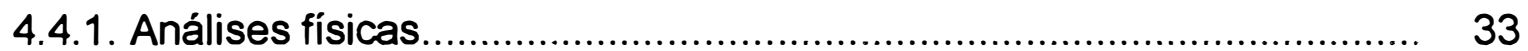

4.4.2. Análises químicas.................................................................. 33

4.4.3. Análise sensorial................................................................... 33

4.4.4. Análise estatística dos resultados ............................................... 34

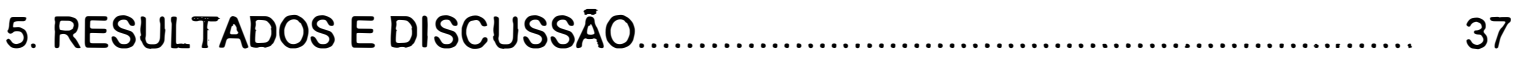

5.1. Caracterização da matéria-prima................................................... 37

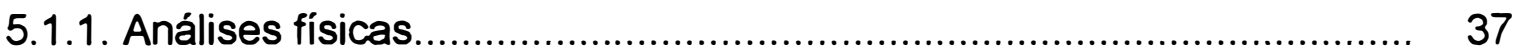

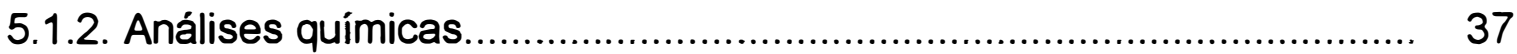

5.2. Caracterização do produto final........................................................ 39

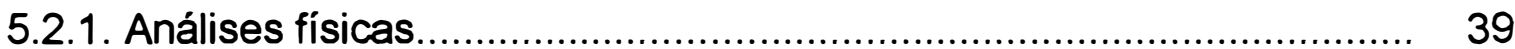

5.2.2. Análises químicas.................................................................... 42

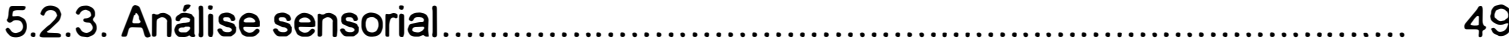

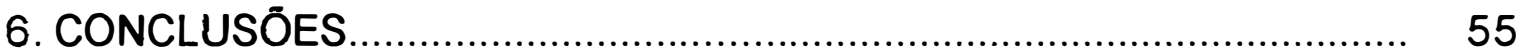

7. REFERÊNCIAS BIBLIOGRÁFICAS .................................................. 57 


\section{LISTA DE FIGURAS}

Página

1 Sazonalidade estimada da comercialização de caixas de $6 \mathrm{Kg}$ de carambola no período de 1992 a 1998, no CEAGESP-SP.

2 Fluxograma das operações utilizadas no processamento das carambolas.

3 Esquema dos tratamentos de pré-processamento aos quais as frutas de cada tipo de carambola foram submetidas.

4 Modelo de ficha utilizado na avaliação sensorial das amostras quanto à textura.

5 Modelo de ficha utilizado na avaliação sensorial das amostras quanto ao sabor.

6 Modelo de ficha utilizado na avaliação sensorial das amostras quanto à cor.

7 Variação da textura (lbf/g de amostra) em função dos tratamentos e períodos de armazenamento - Tipo Doce.

8 Variação da textura (Ibf/g de amostra) em função dos tratamentos e períodos de armazenamento - Tipo Ácido.

9 Variação do teor de vitamina $\mathrm{C}$ (mg de ácido ascórbico / 100g de amostra) em função dos tratamentos e períodos de armazenamento - Tipo Doce.

10 Variação do teor de vitamina $C$ (mg de ácido ascórbico / 100g de amostra) em função dos tratamentos e períodos de armazenamento - Tipo Ácido.

11 Média das notas das avaliações sensoriais em função dos tratamentos 


\section{LISTA DE TABELAS}

Página

1 Resultados das análises físico-químicas da polpa de carambola (Avernoa carambola L.).

2 Definição dos parâmetros dos atributos da análise sensorial................... 36

3 Características físicas da matéria-prima....................................... 37

4 Características químicas da matéria-prima.................................... 38

5 Peso bruto (g) das latas de carambola em calda............................. 41

4 Peso drenado (g) das latas de carambola em calda.......................... 41

5 Vácuo (pol. $\mathrm{Hg})$ das latas de carambola em calda.............................. 43

6 Textura (Ibf/g de amostra) das carambolas em calda............................ 43

$7 \mathrm{pH}$ das carambolas em calda...................................................... 47

10 Teor de vitamina C (mg de ácido ascórbico/100g de amostra) das carambolas em calda.

11 Acidez total titulável ( $g$ de ácido oxálico/100g de amostra) das carambolas em calda.

11 Teor de sólidos solúveis das carambolas em calda.............................. 50

12 Análise sensorial da textura das carambolas em calda.......................... 51

14 Análise sensorial do sabor das carambolas em calda......................... 51

15 Análise sensorial da cor das carambolas em calda......................... 53

16 Avaliação sensorial das carambolas em calda..................................... 53 


\title{
AVALIAÇÃO DE CARAMBOLA (Averrhoa carambola L.) DOS TIPOS DOCE E ÁCIDO, PARA O PROCESSAMENTO DE FRUTA EM CALDA
}

\author{
Autora: Patricia Prati \\ Orientador: Prof. Dr. João Nunes Nogueira
}

\section{RESUMO}

Frutas dos tipos doce e ácido de carambola, provenientes da região Noroeste do estado de São Paulo, foram analisadas fisicamente quanto à textura e rendimento, e quimicamente em termos de $\mathrm{pH}$, acidez total titulável, teor de ácido ascórbico e sólidos solúveis, a fim de determinar suas características para o processamento de fruta em calda.

$\mathrm{Na}$ elaboração das frutas em calda diferentes tratamentos químicos foram empregados (uso de xaropes com diferentes concentrações de sacarose, adição de pectina e cloreto de cálcio em diferentes concentrações, e ácido ascórbico), visando avaliar a adequabilidade dos dois tipos de fruta de carambola para este processamento térmico. Os produtos foram submetidos às análises físicas de peso bruto, peso drenado, vácuo e textura, e, avaliados quimicamente quanto ao $\mathrm{pH}$, acidez total titulável, teor de ácido ascórbico e sólidos solúveis, e sensorialmente quanto à textura, sabor e cor.

Quanto às frutas tipo doce, a adição de cloreto de cálcio e pectina foi efetiva na manutenção de sua textura, uma vez que, os tratamentos adicionados de $0,2 \%$ de cloreto de cálcio, e $0,2 \%$ de pectina $+0,4 \%$ de cloreto de cálcio foram os que apresentaram maiores valores. Já, para o tipo ácido esta prática não surtiu o mesmo efeito, dado que, os tratamentos com adição de 0,1 e $0,2 \%$ de cloreto de cálcio foram avaliados como inferiores àquele cujo xarope foi adicionado de $0,1 \%$ de pectina, fato que indica ser este componente o promotor de boa textura para as frutas ácidas processadas. Ainda pode-se 
observar que este atributo se manteve praticamente constante após 90 dias de estocagem.

Pelos resultados pode-se concluir que os dois tipos de carambola estudados apresentaram, do ponto de vista tecnológico, boas características físicas e químicas, porém as frutas tipo doce foram mais apropriadas para a elaboração de fruta em calda, sendo superiores quanto à textura e sabor, em relação às frutas ácidas. 


\title{
EVALUATION OF TWO KINDS (SWEET AND ACID) OF STAR FRUIT (Averrhoa carambola L.) FOR PROCESSING OF CANNED FRUIT
}

\author{
Author: Patricia Prati \\ Adviser: Prof. Dr. João Nunes Nogueira
}

\section{SUMMARY}

Two kinds of star fruit (sweet and acid) from the Northwest of São Paulo state, were analyzed physically as regards texture and yield, and chemically in terms of $\mathrm{pH}$, titratable acidity, ascorbic acid and soluble solids content, in order to determine their suitability for canned fruit processing.

Different chemical treatments were used for processing the canned fruit (use of syrups with different sacarose concentrations, addition of pectin and calcium chloride in different concentrations and ascorbic acid), in order to evaluate the adequability of the two kinds of star fruit for thermal processing. The products were submitted to the physical analysis of gross weight, drained weight, vacuum and texture, and they were evaluated chemically as regards $\mathrm{pH}$, titratable acidity, ascorbic acid and soluble solids content, and sensorially in terms of texture, flavor and color.

Regarding the sweet kind fruits, the addition of calcium chloride and pectin was effective in the maintenance of its texture, once that, the treatments added with $0,2 \%$ of calcium chloride and $0,2 \%$ of pectin $+0,4 \%$ of calcium chloride showed the better values. For the acid kind this practice didn't produce the same effect, considering that the treatments added with 0,1 and $0,2 \%$ of calcium chloride were evaluated as inferior to that whose syrup was added with $0,1 \%$ of pectin, what indicates that this component is the responsable for the good texture in the processed acid fruits. Also, it was observed that this attribute was kept practically constant after a 90 days of storage. 
Finally it was concluded that both kinds of star fruit studied presented, under a technologic point of view, good physical and chemical characteristics, but the sweet kind of fruits were more apropriated for processing canned fruit, being superior in terms of texture and flavor. 


\section{INTRODUÇÃO}

A caramboleira (Averrhoa carambola L.) é uma planta tropical, pertencente à família das Oxalidaceas e originária da Ásia Tropical; seus frutos denominados carambola, ou em inglês "star fruit", são considerados exóticos, devido ao seu formato ovóide-elipsóide com, normalmente, 5 arestas longitudinais bem salientes, que conferem à fruta, quando cortada em secções transversais, o formato de estrela tornando-a muito atraente ao consumidor (Oliveira et al., 1989; Nagy et al., 1990). O tamanho das frutas pode ser de 10$15 \mathrm{~cm}$ de comprimento, e a cor varia de esbranquiçada a intenso amarelo ouro (Campbell \& Koch, 1989).

A polpa das frutas é abundante e bastante ácida, ou também considerada agridoce, com elevado teor de ácido oxálico, podendo ser consumida em estado natural ou na forma processada como compota, geléia ou bebidas; as frutas imaturas são empregadas no preparo de "picles" (Cavalcante, 1976; Gomes, 1982). Além disso, a polpa contém quantidades apreciáveis de carboidratos, proteínas, vitaminas (principalmente vitamina $\mathrm{C}$ ), fósforo e ácido oxálico, e também propriedades terapêuticas como antitérmica, antiescorbútica, antidisentérica e diuréticas nas afecções dos rins e bexiga (Baldini et al., 1982).

Com características que variam de doce a muito azedo, as frutas doces são consideradas as melhores para consumo "in natura", e, as ácidas são preferidas para processamento (Campbell \& Koch, 1989). Entretanto, mesmo as frutas do tipo doce apresentam uma certa acidez e, por esta razão, normalmente, não são consumidas "in natura", além de que, a população não tem o hábito de consumir carambola. A maioria das frutas que chega ao comércio destina-se ao processamento de sucos, geléias, frutas em calda e extratos, não havendo ainda pesquisas sobre tais técnicas de processamento 
(Kiss, 1998).

A produção de carambolas constitui uma atividade altamente promissora do ponto de vista econômico, devido à qualidade, sabor e formato das frutas, considerados únicos e atraentes. O cultivo de caramboleiras é relativamente novo nos Estados Unidos. O primeiro pomar de carambola foi instalado na Flórida na década de 60, mas somente por volta de 1979 é que a produção dessa fruta passou a aumentar significativamente, sendo que, em 1987 haviam no Sul da Flórida cerca de 75 ha de pomares de carambola contra somente 25 ha em 1985 (Campbell \& Koch, 1989; Matthews, 1989).

No Brasil, a cultura da carambola foi introduzida em 1817 por um agrônomo francês, Paul Germain, que a trouxe da França para Pernambuco, de onde se expandiu para todo o litoral do país, sendo que, em 1856 chegou ao Rio de Janeiro (Granato, 1915; Oliveira et al., 1989; Saúco \& Menini, 1991).

De acordo com os mesmos autores, a difusão do centro de origem (Ásia) para o resto do mundo é bastante recente. Em 1887, a cultura apareceu na Austrália e Flórida; em 1889, em Trinida d-Tobago e em toda área do Caribe; nas Canárias, em 1881; no Brasil, em 1817; na Colômbia, em 1930; em Israel, no ano de 1935; e, na Espanha, em 1988.

Os dados sobre a produção comercial da cultura, tanto no Brasil como no mundo, são bastante antigos e escassos. Informações de cerca de dez anos indicavam como principal país produtor o Taiwan, com uma área de 3100 ha e uma produção de 38270 t. em 1987; tal produção se destinava, principalmente, ao mercado interno, sendo que, uma pequena parte era exportada para o Japão, Hong-Kong, Cingapura e Canadá. Neste mesmo relatório comentava-se que o segundo maior produtor mundial era a Malásia, onde, em 1983, haviam sido plantados 80 ha, em 1987, 265 ha e, em 1989, 896 ha. A produção estimada para 1989 foi de 24000 t. (Campbell \& Koch, 1989; Matthews, 1989).

O Brasil com uma produção estimada em 3000 t. em 1989, foi considerado o terceiro país produtor; atualmente, não se tem informações sobre 
a produção brasileira desta fruta. A área de cultivo se estende por todo o território nacional e até mesmo em algumas áreas da região Sul é possível encontrar pomares de carambola. O principal estado produtor é São Paulo, onde se relatou um consumo de 980 t. em 1988, não havendo dados mais recentes. A sazonalidade da comercialização estimada no CEAGESP-SP no período de 1992-1998 consta na Figura 1 (Araújo et al., 1999). A maioria da produção paulista vem da região noroeste, especificamente do município de Mirandópolis e arredores. No entanto, no Brasil ainda não foi feito um trabalho de seleção voltado para o cultivo comercial, com a fixação, por exemplo, de variedades mais adequadas ao consumo "in natura" (Kiss, 1998; Saúco \& Menini, 1991).

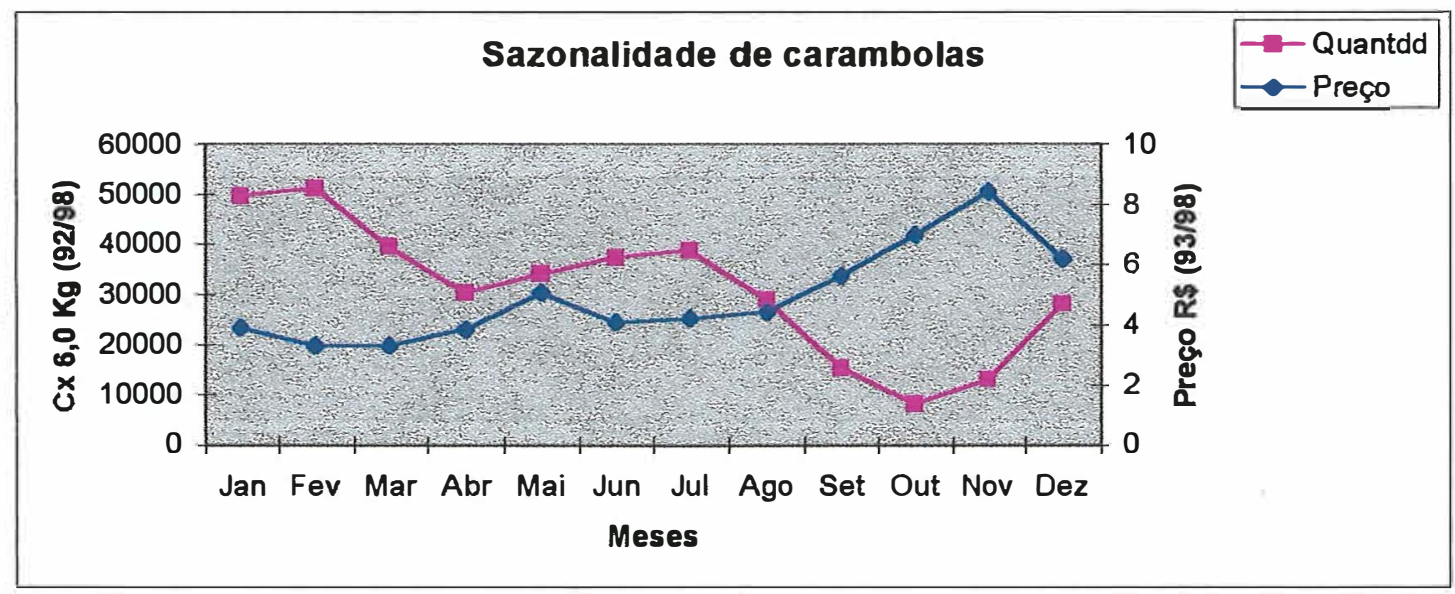

Figura 1. Sazonalidade estimada da comercialização de caixas de $6 \mathrm{Kg}$ de carambola no período de 1992 a 1998, no CEAGESP-SP.

A Flórida também é uma importante região produtora, com uma área de 176 ha, em 1990, sendo que, em 1988-1989 a produção foi de $590 \mathrm{t}$. Informações desta mesma época indicaram outros países que se destacaram como produtores comerciais da fruta: Guiana, Austrália, Tailândia, Israel, Filipinas, Indonésia, Trinida d-Tobago e Suriname (Saúco \& Menini, 1991). 
Considerando o que foi exposto, o desenvolvimento de uma adequada tecnologia de obtenção de carambola em calda e a seleção de "variedades" mais apropriadas a esse processamento térmico poderia estimular a produção, e proporcionar um melhor aproveitamento da fruta, além de agregar valor ao produto final, beneficiando os produtores, as agroindústrias, e os consumidores. 


\section{OBJETIVOS}

O objetivo do trabalho foi desenvolver uma técnica apropriada de processamento de carambola na forma de fruta em calda, visando propiciar uma alternativa de consumo da fruta, incentivando o cultivo, diminuindo perdas pós-colheita, e agregando valor ao produto final, beneficiando com isso os produtores, as agroindústrias e os consumidores. No desenvolvimento da referida tecnologia caracterizou-se física e quimicamente a matéria-prima, e, posteriormente, analisou-se a qualidade do produto processado a fim de se avaliar a adequação de cada tipo de fruta (ácida e doce) ao processamento térmico. 


\section{REVISÃO DE LITERATURA}

\subsection{Considerações gerais}

Segundo Gava (1985), qualidade é o conjunto de características que influe na aceitabilidade de um alimento. Os fatores de qualidade são divididos em quatro categorias: aparência (cor, tamanho, forma, integridade, consistência e defeito); textura (dureza, maciez, suculência, fibrosidade, pegajosidade, arenosidade); gosto (ácido, doce, amargo, salgado); e, aroma (ácido, queimado, metálico).

Os atributos organolépticos e nutricionais dos alimentos vegetais dependem de numerosos fatores como espécie e variedade, condições de cultivo, estado de maturação, condições e duração do armazenamento, e tratamentos tecnológicos, sendo que, a proporção dos diversos constituintes químicos varia consideravelmente durante o desenvolvimento, maturação e armazenamento dos mesmos (Cheftel \& Cheftel, 1988a).

As características organolépticas sempre prevaleceram em relação às nutricionais, dado que, as primeiras definem o grau de qualidade, ou seja, o valor que esses alimentos irão alcançar no mercado (Andrade \& Camargo, 1984). Além de que, mudanças na cor ou odor dos alimentos podem ser uma indicação de mudança no seu valor nutritivo (Desrosier, 1970a). Recentemente os atributos nutricionais também vêm condicionando a compra dos alimentos devido à popularidade alcançada pela Ciência da Nutrição, particularmente, quanto à busca de alimentos que controlam problemas de saúde.

Para muitos consumidores, a aparência (resultado da percepção visual) é o fator mais importante para o julgamento da qualidade de um produto e para sua aceitabilidade (Matz, 1962). 
A demanda de alimentos processados tem aumentado com 0 crescimento da população em núcleos urbanos, e este fato não é devido à escassez de produtos frescos mas à mudança no estilo de vida. Um dos fatores que mais influenciou o desenvolvimento da indústria dos alimentos enlatados, por exemplo, durante os anos 30 , foi a demanda de certos produtos durante todo $\circ$ ano. As técnicas de enlatamento permitiam conservar, por exemplo, ervilha e vagem com qualidade muito superior a dos legumes secos disponiveis no inverno (Holdsworth, 1988).

Entre os procedimentos de conservação de alimentos, o mais empregado é o que consiste em acondicioná-los em um recipiente hermético e submetê-los a um aquecimento que assegure a destruição ou inativação de microrganismos e enzimas responsáveis por alteraçōes (Cheftel \& Cheftel, 1988b).

De acordo com Evangelista (1992) e Fonseca \& Nogueira (1984), a utilização de matéria-prima de boa qualidade e o emprego de técnicas que permitam uma boa conservação das características do produto fresco são pontos extremamente importantes no processamento, que irão influir diretamente na qualidade e aceitação do produto processado.

No caso da matéria-prima, deve-se manuseá-la adequadamente empregando, quando necessário, o armazenamento refrigerado; além disso, a seleção de variedades deve ser feita de acordo com a finalidade a que se destina a matéria-prima, pois uma certa variedade pode ser adequada para um determinado processamento (por exemplo, apertização), e pode não sê-lo para outro (por exemplo, desidratação). Uma vez escolhida a variedade, promove-se a seleção da matéria-prima, pois a mesma deve apresentar tamanho uniforme, ausência (total ou parcial) de defeitos, além de cor, aroma, sabor e textura adequados, sendo que, tais características devem ser preservadas ao máximo durante o processamento (Evangelista, 1992; Fonseca \& Nogueira, 1984).

A fruta utilizada em conserva precisa ser colhida no ponto adequado de maturação, ou seja, não deve estar muito madura e nem muito 
mole como a que será consumida fresca, mas precisa já ter adquirido o sabor característico da fruta madura (Cruess, 1973).

A maioria das frutas é colhida num estágio maduro, porém firme, ou seja, quando atingem pleno desenvolvimento (volume e tamanho), são firmes o suficiente para suportar as condiçōes de manuseio sem sofrer injúrias, e apresentam os atributos cor, sabor e aroma bem desenvolvidos (Prussia \& Woodroof, 1986). As frutas colhidas neste estágio podem tanto ser consumidas "in natura" como também ser destinadas a alguma forma de processamento.

De acordo com Cruess (1973), o início da deterioração de um produto alimentício depende grandemente da quantidade de microrganismos presente no mesmo. $O$ adequado manuseio das frutas durante a colheita, embalagem e transporte garante maior durabilidade desses produtos em boas condições, resultando em um produto final de qualidade superior. Caso contrário, as frutas podem se ferir e se contaminar, favorecendo a proliferação microbiana; neste sentido é recomendada a lavagem de frutas e hortaliças antes de serem processadas, já que tal operação reduz o número de microrganismos presente naturalmente nos vegetais.

A seleção e classificação da matéria-prima antes de ser industrializada resultam num produto final mais uniforme e na padronização e melhoria dos métodos de preparo, tratamento e conservação. $O$ tratamento térmico empregado às frutas e hortaliças enlatadas tem como objetivos tornar o produto estável, evitando as alterações causadas pelos microrganismos, e melhorar a consistência, o sabor e a aparência do produto, mediante o cozimento. $\dot{E}$ importante que se faça o resfriamento das latas após a esterilização, para que o cozimento cesse e o produto não escureça ou tenha sua textura prejudicada (Cruess, 1973).

A industrialização de produtos altamente pereciveis resolve os problemas de grandes perdas, sazonalidade, armazenamento e abastecimento dos grandes centros urbanos apenas com produtos frescos (Teixeira, 1985).

No Brasil, anualmente, cerca de $30 \%$ de toda a produção de frutas 
e hortaliças é perdida, contabilizando toneladas de alimentos não aproveitados. Muitas vezes, tais perdas são responsáveis pelo encarecimento e escassez desses produtos em algumas regiões (Sales et al., 1988).

\section{2. "Variedades" de carambola}

Atualmente, o principal problema do cultivo de caramboleiras no Brasil é a falta de pesquisas sobre variedades. Estudos têm sido desenvolvidos procurando selecionar frutas doces e ácidas para chegar à definição de cultivares que permitam a expansão do consumo dessa fruta (Kiss, 1998).

Nos Estados Unidos, os pesquisadores referem-se a dois cultivares: Arkin (tipo doce) e Golden Star (tipo ácido), sendo o cultivar Arkin, o principal na produção comercial, porque possui excelente sabor e resistência a danos de manuseio (Matthews, 1989).

A composição química das frutas pode variar dependendo do cultivar, condições climáticas, localização, condições de irrigação, tipo de solo e ano de cultivo, sendo que, as características químicas dos tipos doce e ácido afetam a qualidade final do produto processado (Joseph \& Mendonca, 1989a).

Oliveira et al. (1989) estudaram as características físico-químicas da polpa das frutas de Averrhoa carambola L. (variedade não identificada), coletadas na Estação de Fruticultura da Empresa de Pesquisa Agropecuária do Ceará, cujos resultados podem ser observados pela Tabela 1.

\subsection{Fatores que afetam a qualidade da carambola}

\subsubsection{Características das frutas}

Logo após a colheita, os alimentos estão sujeitos a alterações que podem ocorrer no seu manuseio, transporte, processamento $e$ armazenamento. Essas alterações podem ser de três tipos: biológica, química e 
física. No caso de processamento de frutas, as alterações enzímicas são de suma importância, uma vez que, podem levar o alimento ao escurecimento (Caruso \& Camargo, 1984; Evangelista, 1992; Gava, 1985).

Tabela 1. Resultados das análises físico-químicas da polpa de carambola (Averrhoa carambola L.).

\begin{tabular}{|c|c|}
\hline Determinações * & Resultados \\
\hline Umidade & $90,21 \%$ \\
\hline Proteina & $0,43 \%$ \\
\hline Lípidios & $0,16 \%$ \\
\hline Fibra & $0,56 \%$ \\
\hline Cinza & $0,40 \%$ \\
\hline Amido & $1,86 \%$ \\
\hline Glicidios redutores & $4,07 \%$ (em glicose) \\
\hline Glicidios não redutores & - \\
\hline Glicidios totais & $5,93 \%$ \\
\hline $\mathrm{pH}$ & 3,33 \\
\hline Sólidos solúveis & $5,10^{\circ}$ Brix \\
\hline Acidez total titulável & 0,37\% (em ácido cítrico) \\
\hline${ }^{\circ}$ Brix / acidez & $13,78^{\circ}$ Brix \\
\hline Ácido ascórbico & $17,16 \mathrm{mg} / 100 \mathrm{~g}$ \\
\hline Fósforo & $15,20\left(\mathrm{mg} \mathrm{P}_{2} \mathrm{O}_{5} / 100 \mathrm{~g}\right)$ \\
\hline Cálcio & $22,60 \mathrm{mg} / 100 \mathrm{~g}$ \\
\hline Ferro & $0,44 \mathrm{mg} / 100 \mathrm{~g}$ \\
\hline Tanino & $156,60 \mathrm{mg} / 100 \mathrm{~g}$ \\
\hline Pectina & $0,50 \%$ \\
\hline
\end{tabular}

* Média de 3 determinações.

Fonte: Oliveira et al., 1989.

Segundo Desrosier (1970a), durante a estocagem das conservas as reações químicas podem ocorrer afetando o sabor, odor, cor, textura e o valor nutritivo dos alimentos.

De acordo com Andrade \& Camargo (1984), o simples armazenamento em temperatura ambiente pode levar os alimentos à perda de vitaminas (como a vitamina $\mathrm{C}$ ), que no caso de hortaliças pode se reduzir à metade após um dia de armazenamento nessas condições.

Quando as frutas entram em senescência, muitas mudanças 
químicas e fisiológicas ocorrem, fato que é evidenciado pela perda da cor verde. Tais mudanças envolvem a degradação da clorofila, e a exposição dos carotenóides que são pigmentos amarelos. Normalmente, esta mudança de cor é acompanhada por uma mudança na textura da fruta (Eskin et al., 1971).

Segundo os mesmos autores, o desenvolvimento de um sabor agradável característico para uma determinada fruta envolve um decréscimo da acidez e um aumento no conteúdo de açúcares. As substâncias responsáveis pelo sabor das frutas não maduras são taninos e compostos fenólicos, que conferem às mesmas um gosto adstringente. Como pode ser observado pela Tabela 1, o conteúdo de tanino em frutas de caramboleira é de $156,60 \mathrm{mg} / 100 \mathrm{~g}$ (Oliveira et al.; 1989).

A colheita manual de carambolas é complicada pois as frutas sofrem danos facilmente, devido à epiderme fina, frágil e também ao seu formato nervado (Campbell et al., 1989). Pelo fato de ser extremamente delicada e perecível, a carambola deve ser cuidadosamente coletada, classificada, transportada e comercializada; alguns produtores de Cedral (SP), para evitar que o manuseio machuque as carambolas durante a colheita, usam um pequeno espelho que é colocado embaixo da fruta, e a imagem refletida revela se é o momento ideal de colher (Kiss, 1998).

As frutas da caramboleira são climatéricas, e por esta razão podem ocorrer no pós-colheita mudanças na cor, e nos teores de ácidos orgânicos e sólidos solúveis (Campbell et al., 1989). Quanto aos ácidos, o oxálico tem sido identificado como o principal ácido em carambola e, quanto mais madura a fruta, maior o teor do ácido, apresentando as frutas do tipo doce menor concentração do mesmo (Joseph \& Mendonca, 1989a).

De acordo com Campbell et al. (1989), a fase pós-colheita das carambolas é muito curła, o que gera problemas na distribuição comercial das mesmas. A estocagem refrigerada, entretanto, é um efetivo meio de prolongar a vida comercial de muitas frutas.

Campbell et al. (1989) instalaram experimentos para avaliar o 
efeito da refrigeração $\left(5\right.$ e $\left.10^{\circ} \mathrm{C}\right)$ sobre a qualidade das frutas da caramboleira, e verificaram que em temperaturas mais baixas $\left(5^{\circ} \mathrm{C}\right)$ ocorria menor perda de peso, menos escurecimento e menos descarte de frutas. As concentrações de sólidos solúveis e de ácidos orgânicos também permaneceram similares às das frutas recém colhidas, quando armazenadas a $5{ }^{\circ} \mathrm{C}$. Portanto, a estocagem da carambola a $5^{\circ} \mathrm{C}$ é efetiva na redução da deterioração fisiológica das frutas depois da colheita e preservação de sua aparência sem injúrias pelo frio.

As mudanças de cor, sabor, odor e valor nutritivo das frutas podem ocorrer também durante o processamento, neste caso, podendo ser controladas pela redução de temperatura, nível de oxigênio, e pela aplicação de inibidores oxidativos como o dióxido de enxofre (Shewfelt, 1975).

\subsubsection{Ação das enzimas}

A principal enzima presente nas frutas é a polifenoloxidase, que se trata de uma óxido-redutase, já que catalisa as reações oxidativas de compostos fenólicos a orto-quinonas, as quais polimerizam e/ou interagem com proteínas ou aminoácidos, para produzir compostos escuros, como as melanoidinas. Esta seqüência de reações é conhecida como escurecimento enzímico e se constitui num dos mais graves problemas do processamento de frutas e hortaliças (Montgomery, 1991). Segundo Eskin et al. (1971), as reações de escurecimento em alimentos, tornam-se evidentes, quando os mesmos são submetidos ao processamento ou sofrem injúrias mecânicas.

As enzimas que provocam alteraçōes nos alimentos podem ser naturais ou elaboradas por microrganismos. As alterações que ocorrem devido a ação de enzimas do próprio produto não resultam em compostos nocivos, mas, principalmente, em modificações de suas características organolépticas (aparência, sabor e odor) e de seu valor nutritivo (Eskin et al., 1971; Evangelista, 1992)

Segundo laderoza \& Draetta (1991), as enzimas naturais presentes nos vegetais podem contribuir positivamente, melhorando o sabor, a 
textura ou a aparência do alimento, como também podem induzir a reações indesejáveis como o escurecimento. No processamento de frutas, a ação enzímica assume grande importância pois uma vez danificadas, as células liberam as enzimas e as reações ocorrem descontroladamente, causando transformações indesejáveis como alteraçōes na cor dos alimentos, destruição de substâncias pécticas, degradação de vitaminas e aparecimento de sabor estranho.

De acordo com Sales et al. (1988), o escurecimento enzímico é provocado pela ação de enzimas oxidativas (como a peroxidase e a polifenoloxidase) sobre os substratos naturais da fruta, produzindo com isso substâncias coloridas, e, até mesmo alterando o sabor e aroma do vegetal. A peroxidase catalisa a oxidação de um composto fenólico (guaiacol) por meio do peróxido de hidrogênio o que resulta num composto colorido.

As enzimas também podem alterar a textura ou consistência dos vegetais e dos produtos industrializados de frutas e hortaliças, devido à sua atuação sobre substâncias pécticas, como demetoxilantes e/ou despolimerizantes desses compostos. Além disso, a degradação de vitaminas também ocorre, e pode ser resultante de reações oxidativas catalisadas pelas enzimas. Dentre estas reações as mais importantes são a oxidação do ácido ascórbico pela ascorbicoxidase, peroxidase e polifenoloxidase e, a oxidação da vitamina A e pró-vitamina A (carotenos) pela lipoxidase (Sales et al., 1988).

Ainda podem ser citadas as reações responsáveis pelo aparecimento de odores e sabores estranhos no produto final, que são catalisadas por enzimas oxidativas como a peroxidase e a catalase. Tais reações são importantes durante a fase de armazenamento de produtos de frutas e hortaliças congeladas (Paschoalino, 1991).

De acordo com Menezes (1991), a maior ou menor atividade enzimática depende de fatores como concentração da enzima, concentração do substrato, $\mathrm{pH}$, temperatura, presença de inibidores ou ativadores e, a atividade de água. Alguns desses fatores podem, por via química ou física, conduzir a 
mudanças estruturais reversíveis ou irreversíveis, afetando a atividade da enzima.

Segundo Gava (1985), a maioria das enzimas pode ser inativada na faixa de temperatura de $70-80^{\circ} \mathrm{C}$, durante 2 a 5 minutos. Eskin et al. (1971) afirmam que o emprego de calor (branqueamento) é o método mais usado para o controle do escurecimento enzímico, pois é mais efetivo na inativação da polifenoloxidase. Segundo Desrosier (1970a), a inativação das enzimas pelo calor é devida à quebra da molécula de proteína, com dissociação e perda de estrutura. No entanto, Silva \& Nogueira (1983) citam que a atividade da polifenoloxidase encontrada em frutas como pera, figo, banana, maçã e pêssego, é pouco afetada pelo calor.

Quanto ao pH, Reed (1966) afirma que um simples ajuste no $\mathrm{pH}$ dos produtos de frutas para níveis alcalinos aparenta exercer um efeito considerável na prevenção da reação de escurecimento.

Outros métodos de controle da polifenoloxidase em alimentos são o emprego de agentes quelantes, o uso do ácido ascórbico, sulfitos (gás ou solução de bissulfito de sódio), cloreto de sódio, ácidos (ácido cítrico) e a exclusão de oxigênio.

Segundo Weller et al. (1997) o emprego de ácido cítrico e ácido ascórbico ou eritórbico tem sido efetivo no controle do escurecimento enzímico de carambolas fatiadas. Esses autores verificaram que carambolas fatiadas, embaladas e estocadas a $4,4^{\circ} \mathrm{C}$ por mais de 2 semanas, escureceram significativamente quando expostas ao ar; em contraste, as frutas inteiras, embaladas e estocadas nas mesmas condições por 6 semanas, escureceram pouco quando expostas ao ar por cerca de 6 horas. Tal fato foi devido ao aumento da atividade da polifenoloxidase em razão do fatiamento (injúrias) da fruta.

No caso da polifenoloxidase, Almeida \& Nogueira (1995) afirmam que o método mais eficiente e de baixo custo no controle da atividade dessa enzima é o uso de dióxido de enxofre. No entanto, o uso de tal agente 
apresenta algumas desvantagens como 0 efeito negativo na textura, 0 desenvolvimento de sabores e odores estranhos, e ainda, a eventual corrosão de latas, bem como a destruição da tiamina (vitamina B1). Assim, esses autores pesquisando novos métodos para o controle da atividade da polifenoloxidase concluíram que a alternativa mais adequada para substituir o uso de dióxido de enxofre foi a combinação de ácido ascórbico, ácido cítrico e tratamento térmico.

\subsubsection{Alterações de pigmentos}

A cor é um dos fatores importantes na determinação da qualidade dos produtos de frutas (Shewfelt, 1975). Vários métodos oficiais para avaliar a qualidade dos alimentos se baseiam na cor pelo fato desta, freqüentemente, estar ligada a maturação, presença de impurezas, realização apropriada ou não de um tratamento tecnológico, más condições de armazenamento e indício de alteração por microrganismos (Cheftel \& Cheftel, 1988b).

$A$ aceitabilidade de um alimento no mercado é muito dependente de sua cor, porém ocorrem diferenças de aceitação em função, por exemplo, de fatores geográficos, sendo que, um atributo considerado aceitável para certos indivíduos, pode não ser para outros. O fato é que os alimentos apresentam uma cor característica, que quando se desvia daquela esperada pelo consumidor, passa a impressão de que 0 alimento está deteriorado e/ou processado inadequadamente (Prado Filho \& Prado, 1992; Richards, 1996).

As mudanças de cor em frutas e produtos de frutas podem ser causadas pela oxidação enzimática de pigmentos ou precursores de pigmentos, tais como taninos e catecóis, contendo grupamento ortodihidroxi. Tal oxidação pode ser evitada pela inativação das oxidases pelo calor, estocagem a baixas temperaturas e pela redução do pH (Tauber, 1950).

Segundo laderoza \& Draetta (1991), os pigmentos naturais mais comuns em frutas são as antocianinas (flavonóides) e os carotenóides. As antocianinas são pouco estáveis, podendo ser degradadas no próprio tecido ou durante o processamento e armazenamento do vegetal. Tais alterações estão 
relacionadas com variações no $\mathrm{pH}$, na temperatura, adição de antioxidantes, presença de metais (em produtos enlatados), e presença de carboidratos e aminoácidos.

Os carotenos e carotenóides são pigmentos naturais, variando da cor amarela ao vermelho escuro, presentes nos cloroplastos dos vegetais, porém mascarados pela presença da clorofila. Com o amadurecimento das frutas ou senescência das hortaliças, a mudança de cor ocorre devido à destruição da clorofila. Uma das mais importantes funções desses pigmentos é servir como corante dos alimentos (Tapia-Tapia et al., 1993). Os carotenóides são mais estáveis que as antocianinas, apresentando boa estabilidade na faixa de $\mathrm{pH}$ da maioria dos alimentos, não sendo destruídos por substâncias redutoras como o ácido ascórbico (laderoza \& Draetta, 1991).

A estabilidade destes pigmentos é dependente de fatores como temperatura, disponibilidade de oxigênio, exposição à luz, aminoácidos, presença de metais, e acidez; mas também a variedade, maturidade, local de origem, mudanças climáticas e sazonais, e vários métodos de processamento, afetam a coloração natural proporcionada pelos mesmos (laderoza \& Draetta, 1991; Prado Filho \& Prado, 1992).

As causas de destruição de carotenos e carotenóides durante o processamento e estocagem do alimento são: a oxidação (em produtos desidratados, por exemplo), o emprego de calor, o tratamento com solventes solúveis em água como álcool e acetona, a ação enzimática e a irradiação (Prado Filho \& Prado; 1992; Tapia-Tapia et al., 1993).

Porém o principal fator que leva tais substâncias à degradação é a oxidação. Maiores tempos e temperaturas de cocção foram claramente associados com a maior degradação de carotenóides analisados em cenoura (Sant'ana, 1995).

Segundo Salunkhe \& Bolin (1974), o branqueamento como prétratamento tem evitado a destruição por ação enzimática desses pigmentos, resultando somente em $5 \%$ de perdas contra $80 \%$, quando o produto não passa 
por tal tratamento térmico.

A oxidação por ação enzimática pode ser devida às lipoxigenases (formalmente conhecidas como lipoxidases ou caroteno oxidases) encontradas em todas as plantas superiores (O'Connor \& O'Brien, 1991).

Considerando que todas as substâncias dessa natureza são susceptiveis à destruição oxidativa, pode-se obter um efeito estabilizador pela adição de um antioxidante à produtos contendo carotenos, sendo a etoxina considerada o melhor antioxidante adicionado à tais preparados alimentícios (Prado Filho \& Prado, 1992). No caso de sucos e outras bebidas, o antioxidante usado é o ácido ascórbico, e, para melhorar a estabilidade dos carotenos na estocagem de enlatados e de flocos pré-cozidos e desidratados de batata-doce, tem-se utilizado BHT e BHA em misturas com ácido cítrico ou pirofosfato ácido de sódio (Tapia-Tapia et al., 1993).

Muitas vezes, o oxigênio dissolvido no produto e/ou presente no espaço livre já é suficiente para desencadear reações de oxidação, não bastando apenas a barreira da embalagem ao oxigênio. Logo, a desaeração do produto antes do acondicionamento e o emprego de técnicas que reduzam o espaço livre ou que diminuam a concentração do oxigênio no espaço livre irão contribuir decididamente para aumentar a vida útil do produto (Alvez \& Garcia, 1993).

\subsubsection{Alterações na textura}

A textura pode ser considerada como uma manifestação das propriedades reológicas de um alimento e constitui um atributo importante de qualidade, exercendo influência nos hábitos alimentares, na preferência do consumidor, e afetando o manuseio e processamento dos alimentos. É, freqüentemente, a sinalizadora no reconhecimento de produtos estragados (Mori, 1989).

A textura dos alimentos exerce grande influência sobre a aceitação destes no mercado, além de que, a avaliação das características de 
textura pode se constituir em um parâmetro determinante de condiçōes de processamento pois, matérias-primas de textura branda submetidas à cocção intensa, resultam em produtos extremamente macios (moles). Também, alguns testes de avaliação das características de textura podem ser úteis no melhoramento genético de variedades de frutas e hortaliças, quando se visa o aprimoramento e adequação destes produtos ao comércio "in natura" ou como industrializados (Campos, 1989).

A textura de frutas e hortaliças é conferida por substâncias pécticas presentes nos seus tecidos, tais como ácidos pécticos, pectina e protopectina. Tais substâncias são encontradas na lamela média e nas paredes celulares, e têm a função de conferir firmeza (textura) aos tecidos vegetais. Com o amadurecimento das frutas ou senescência das hortaliças, tais produtos perdem gradativamente sua textura tornando-se mais macios; isto ocorre devido à degradação das substâncias pécticas por enzimas pécticas que podem ser endógenas (presentes em plantas superiores) ou serem produzidas por microrganismos (Eskin et al., 1971; Pilnik \& Voragen, 1991).

De acordo com Eskin et al. (1971), as pectinas podem ser classificadas em solúveis e insolúveis; a porção solúvel consiste numa longa cadeia de ácido poligalacturônico com grupos carboxílicos parcialmente esterificados. Já, a pectina insolúvel ou protopectina (encontrada em frutas não maduras) consiste numa longa cadeia de ácido poligalacturônico com grupos metílicos associados ao cálcio, formando o pectato de cálcio localizado na lamela média entre as paredes celulares adjacentes. A pectina insolúvel tornase solúvel por transformação enzimática que ocorre durante o amadurecimento. De acordo com Oliveira et al. (1989), o teor de pectina em frutos de caramboleira é de $0,5 \%$ (Tabela 1 ).

Segundo Eskin et al. (1971) e Pressey (1977), o amolecimento das frutas é devido ao colapso da lamela média e das paredes celulares, provocado pela ação de enzimas como as protopectinases, pectinesterases (PE) e poligalacturonases $(P G)$, as quais são menos ativas em frutas não maduras 
devido à presença de inibidores naturais. A desesterificação (retirada de grupos metílicos) das cadeias de pectina pode também ser favorecida pelo processamento térmico aplicado às frutas.

De acordo com Conti (1989), as pectinesterases ou pectases desesterificam as substâncias pécticas produzindo metanol e ácido péctico. Já, as poligalacturonases ou pectinases, ou ainda pectolases (de-polimerases) por hidrólise agem sobre as ligações glicosídicas $\alpha-1,4$ da cadeia do ácido poligalacturônico (constituinte dos ácidos pécticos e pectínicos), resultando em uma cadeia menor de ácido poligalacturônico ou em unidades de ácido galacturônico (Conti, 1989; Kertesz, 1951). Kertesz (1951), ainda afirma que quanto menor o grau de esterificação da cadeia, maior a velocidade de ação da enzima. O autor define como protopectinases enzimas que hidrolizam ou degradam a protopectina, atuando sobre as ligações glicosídicas $\alpha-1,4$ da cadeia do ácido poligalacturônico que compõe as protopectinas.

A adição ou imersão de produtos de frutas em sais de cálcio proporciona maior firmeza desses tecidos devido à formação de pectato de cálcio resultante da interação do cálcio com a pectina degradada na lamela média. O tratamento de substâncias pécticas com ácidos proporciona a demetilação e a quebra da cadeia do ácido poligalacturônico, assim como a solubilização da protopectina. Já, o tratamento com álcalis promove a demetilação do ácido pectínico, e, a protopectina pode ser decomposta pela adição excessiva de hidróxido de sódio ou potássio. A adição de fortes soluçōes

alcalinas aos ácidos pectínicos ou pectatos resulta na formação de gel; neste caso, quando se usa hidróxido de sódio ou potássio o gel formado se dissolve em um excesso do álcali, e, quando se emprega hidróxido de cálcio ou bário forma-se um gel forte que não se dissolve com o excesso do reagente (Kertesz, 1951).

\subsubsection{Outros fatores importantes}

O uso de embalagens metálicas pode ocasionar alteração da cor 
de alimentos pigmentados e intensamente coloridos, uma vez que esses produtos são altamente corrosivos (mesmo na ausência de oxigênio) e sofrem descoloração por ação do estanho. Além disso, durante o aquecimento de alimentos ácidos, o estanho se desprende, o que resulta em toxicidade pela presença do metal em produtos como sucos de frutas (Chesca et al., 1993). Apesar disso, tem-se dado maior preferência aos recipientes metálicos do que aos vidros, uma vez que são menos frágeis permitindo maior facilidade de manuseio e conduzem melhor o calor possibilitando obter menor tempo de esterilização (Jackix, s.d.).

Os dois tipos de alterações a que os alimentos enlatados estão sujeitos são as alterações por ação de microrganismos (abaulamento, fermentação não gasosa - "flat sour", aparência e odor anormais, turbidez da calda e presença de depósitos brancos) e as mudanças causadas por agentes químicos ou físicos (oxigênio; reações de sulfeto de cobre ou de ferro com o alimento; reação dos aminoácidos com hexoses ou reação de Maillard, comum em frutas secas, geléias e xaropes de frutas; estufamento por superenchimento; e estufamento devido a baixo vácuo) (Cruess, 1973; Jackix, s.d.).

De acordo com Fernandes (1982), a vida útil de alimentos enlatados é avaliada pela migração de metais como o estanho, ferro e chumbo para o produto, devido à corrosão da folha-de-flandres. A corrosão pode ocorrer devido a três fatores: produto (acidez, viscosidade, e presença de agentes oxidantes, como o estanho); condições de estocagem (temperatura, umidade relativa do ambiente; luz, e presença de sais); e tipo de embalagem, cuja escolha deve ser feita em função da resistência do material ao ataque dos componentes dos alimentos (Evangelista, 1992; Fernandes, 1982).

Segundo Chesca et al. (1993), algumas medidas para prevenção e controle da corrosão em folha-de-flandres podem ser utilizadas, como o emprego de verniz interno, substâncias inibidoras, minimização da presença de oxigênio, e uso de folha-de-flandres especial. Frutas ácidas podem promover a corrosão e perfuração da folha estanhada; para que este fato seja evitado, 
recomenda-se a exaustão completa das frutas enlatadas, enchimento completo e uniforme da lata e vedamento eficiente, a fim de reduzir ao máximo a quantidade de ar dentro do recipiente. A presença do oxigênio dentro da lata, durante 0 tratamento industrial e pouco depois deste, pode intensificar a corrosão inicial da lata e, assim, favorecer a corrosão subsequente na ausência do oxigênio (Cruess, 1973).

A ingestão de alimentos com elevadas quantidades de sais metálicos provoca intoxicação, sendo que, os sintomas mais comuns são dores intestinais, vômitos e náuseas (Chesca et al., 1993).

\subsubsection{Aplicação do calor}

A preservação e conservação dos alimentos se impõem em todas as fases que precedem ao consumo, e se baseiam em processos que visam a destruição parcial ou total dos microrganismos deterioradores e a inativação de enzimas indesejáveis (Evangelista, 1992).

Sob o ponto de vista econômico, a conservação de frutas pelo calor é o processo que assume maior importância (Fonseca \& Nogueira, 1984). O objetivo do tratamento térmico dos alimentos é assegurar a destruição de todos os organismos vivos capazes de deteriorar os alimentos ou prejudicar a saúde do consumidor (Baumgartner \& Herson, 1959). A morte dos microrganismos pelo calor é devida à coagulação de proteínas e, especialmente, à inativação de enzimas necessárias ao seu metabolismo (Fonseca, 1976).

A tolerância dos microrganismos ao calor é fortemente afetada pelo $\mathrm{pH}$ dos alimentos, sendo que, alimentos pouco ácidos $(\mathrm{pH}>4,5)$ devem ser esterilizados em temperaturas superiores a $100^{\circ} \mathrm{C}$, pois os esporos dos microrganismos que ocorrem neste tipo de produto são termorresistentes. Já, os alimentos ácidos $(\mathrm{pH}<4,5)$ são submetidos a um tratamento térmico menos severo (aquecimento em temperaturas menores ou iguais a $100^{\circ} \mathrm{C}$ ) pois os microrganismos e esporos que ocorrem nesses alimentos são menos 
resistentes ao calor. Outros fatores que também influem na resistência dos microrganismos ao calor são: umidade do alimento, tipo de ácido, açúcar, sais inorgânicos e gorduras presentes (Fonseca, 1976).

Um tratamento térmico moderado é suficiente para a apertização dos produtos ácidos; por um lado, os microrganismos morrem mais facilmente pelo aquecimento quando $\circ \mathrm{pH}$ é baixo e por outro, as espécies esporuladas termorresistentes não se desenvolvem em meio ácido. Há preocupação somente com as leveduras e bolores e, com algumas outras espécies que também são termolábeis mas, de um modo geral, o aquecimento por 15 minutos a $85-90^{\circ} \mathrm{C}$, por exemplo, permite eliminá-las (Cheftel \& Cheftel, 1988b).

No entanto, de nada adianta livrar um alimento dos agentes deterioradores (microrganismos ou enzimas) se desse tratamento resultar um sabor e/ou cor desagradáveis e se suas propriedades nutritivas forem destruídas. Por isso, deve-se usar o calor, por exemplo, somente para destruir os microrganismos potencialmente deterioradores (Fonseca, 1976).

Os métodos de conservação de alimentos pelo calor incluem apertização, secagem e concentração, sendo que, dentre estes, a apertização, constitui o de maior importância industrial, mundialmente empregado, não só na grande, como também na média e pequena indústria (Gava, 1985).

As conservas "apertizadas" foram definidas como sendo produtos alimentícios, de origem vegetal ou animal, cuja conservação está assegurada pelo emprego combinado das técnicas de acondicionamento em um recipiente hermético e tratamento pelo calor, sendo que, este tratamento deve destruir ou inibir totalmente as enzimas, assim como os microrganismos e suas toxinas, cuja presença ou proliferação poderia alterar o produto ou torná-lo impróprio para a alimentação humana (Cheftel \& Cheftel, 1988b).

O calor pode ser aplicado também como método para o controle do escurecimento enzímico em alimentos, em processos como o branqueamento e a pasteurização empregados como pré-tratamentos de frutas 
e hortaliças para congelamento, desidratação, elaboração de sucos, purês e outros produtos. No entanto, o binômio tempo-temperatura deve ser bem determinado, pois a aplicação de calor implica no cozimento de frutas e hortaliças, e isto causa mudanças de sua textura e sabor (Eskin et al., 1971).

Segundo Soler et al. (1991), dentre os diversos produtos que podem ser obtidos das frutas, destaca-se a fruta em calda, sendo considerado produto de primeira linha nas indústrias de conservas de frutas e de larga aceitação pelos consumidores em todos os continentes. Os autores ainda definem fruta em calda como sendo "o produto obtido de frutas, inteiras ou em pedaços, com ou sem sementes ou caroços, com ou sem casca, submetidas a cozimento incipiente, enlatadas ou envidradas praticamente cruas, cobertas com calda de açúcar, e que após fechamento em recipientes, são submetidas a um tratamento térmico adequado". A calda ou líquido de cobertura é usada para preencher os interstícios (facilitando a transmissão de calor), para promover a remoção de ar e realçar o sabor das frutas. A legislação brasileira estabelece para frutas em calda, de um modo geral, a concentração de 14 a $40^{\circ} \mathrm{Brix}$ (Jackix, s.d.).

O uso do calor como método de conservação, pode implicar em alteração no valor nutritivo do produto, além de modificações químicas e físicas, dependendo da intensidade e tempo de exposição ao calor (Evangelista, 1992). A textura e a palatabilidade dos alimentos podem ser afetadas pelo simples ato de cozinhar ou fritar esses produtos antes de seu consumo (Gava, 1985).

Em relação à perda de nutrientes, as etapas mais críticas do processamento de fruta em calda são a exaustão e a esterilização (Sales et al., 1988).

De acordo com Sturion et al. (1991), o branqueamento pode provocar perdas por oxidação ou lixiviação das vitaminas, sendo a oxidação o fator predominante de perda durante a pasteurização; no entanto, produtos ácidos ou em meio ácido são mais estáveis nesse caso. Por sua vez, a esterilização comercial pode promover a retenção de nutrientes, já que neste 
tratamento térmico se emprega altas temperaturas por curto tempo.

O ácido ascórbico, por exemplo, é hidrossolúvel sendo perdido facilmente por lixiviaçāo, durante o preparo do produto e/ou durante 0 aquecimento do mesmo, e por oxidaçāo, especialmente quando o alimento está em contato com o cobre, ferro ou enzimas oxidativas (Sturion et al., 1991). A carambola possui como principal vitamina, o ácido ascórbico e o teor encontrado por Oliveira et al. (1989) pode ser observado pela Tabela 1.

Como exemplos da ação do calor, Sturion et al. (1991) citam perdas de $16-58 \%$ das vitaminas (principalmente, a vitamina $C$ ), pelo método de branqueamento com o emprego de água, enquanto que, com o emprego de vapor tem-se perdas de $16-26 \%$; já, no caso da pasteurização do leite pelo emprego de alta temperatura/tempo curto as perdas chegam a $10 \%$, enquanto que pelo método tradicional alcançam cerca de $20 \%$.

$\mathrm{O}$ aquecimento dos alimentos em altas temperaturas e por curto tempo resulta numa menor degradação dos pigmentos naturais, e menores perdas do sabor, odor e textura originais, e de vitaminas, principalmente, as hidrossolúveis (tiamina, riboflavina e ácido ascórbico) que são pouco a moderadamente estáveis ao calor (Desrosier, 1970b).

Em autoclaves, os produtos podem perder cerca de $80 \%$ de vitamina B1 (tiamina). Já, as perdas de ácido ascórbico podem ser significativas devido à presença de oxigênio, ou de íons cobre ou da ácido ascórbico oxidase, durante $O$ aquecimento. No entanto, as vitaminas lipossolúveis $A, D$ e $E$ são relativamente termo-estáveis, podendo ocorrer perdas apreciáveis quando 0 aquecimento se dá na presença de oxigênio (Fonseca, 1976).

\subsubsection{Processamento de carambola}

$\mathrm{Na}$ Guiana, a carambola é processada como compota (fruta fervida em xarope de açúcar), sendo que, alguns estudos têm indicado que um aceitável produto pode ser preparado por desidratação osmóstica em xarope de açúcar de alta concentração. $\mathrm{O}$ xarope obtido do processo de desidratação 
pode ser diluído e usado como bebida, ou então temperado e cozido para preparar um molho de churrasco. $O$ retomo financeiro desses xaropes contribui substancialmente para tornar o processamento de carambola uma atividade economicamente viável (Joseph \& Mendonca, 1989b).

Neste sentido, Joseph \& Mendonca (1989b) realizaram estudos para determinar a melhor concentração inicial do xarope, a taxa de aumento na concentração do xarope, e a aceitabilidade de consumo do produto processado. Quanto à concentração inicial do xarope os maiores rendimentos foram obtidos com o processamento da fruta em xaropes de baixa concentração inicial (10 e $20^{\circ}$ Brix). Quanto a taxa de aumento na concentração do xarope os melhores resultados de rendimento, umidade e sólidos solúveis totais foram obtidos com o tratamento $30 / 10 / 24$ (concentração inicial de $30^{\circ}$ Brix, com aumento de $10^{\circ}$ Brix a cada 24 horas). Já, quanto à aceitabilidade de consumo, os produtos elaborados com frutas processadas em açúcar cristal marrom, como bolo de frutas, sorvetes, sobremesas de frutas, foram mais aceitos pelos consumidores do que aqueles que foram preparados com frutas processadas em açúcar branco.

Matthews (1989) estudou a potencialidade da carambola na elaboração de sucos elaborando três combinações com volumes iguais de suco de carambola e de goiaba, suco de carambola e de abacaxi, e, suco de carambola e de laranja. $\mathrm{O}$ autor concluiu que combinações de suco elaboradas com $50 \%$ de suco de carambola e sucos de abacaxi ou goiaba tiveram boa aceitabilidade, segundo análise sensorial para sabor. Esse estudo indica que a carambola possui potencial para utilização em combinações com sucos de frutas tropicais. 


\section{MATERIALE MÉTODOS}

As atividades desta pesquisa foram desenvolvidas no Setor de Processamento de frutas e hortaliças do Departamento de Agroindústria, Alimentos e Nutrição da Escola Superior de Agricultura "Luiz de Queiroz" Universidade de São Paulo.

\subsection{Matéria-prima}

Foram utilizadas frutas de carambola (Averrhoa carambola L.) dos tipos doce e ácido, plenamente desenvolvidas e com coloração predominantemente amarelada. Todas as frutas foram provenientes da região de Mirandópolis, estado de São Paulo, onde estudos sobre a cultura estão sendo desenvolvidos por pesquisadores do Departamento de Produção Vegetal, ESALQ/USP.

\subsection{Caracteristicas da matéria-prima}

\subsubsection{Análises físicas}

a) Rendimento: Foi determinado utilizando amostras de $1000 \mathrm{~g}$ de frutas tomadas aleatoriamente dos lotes do material. Inicialmente, as carambolas de cada amostra foram pesadas em balança semi-analítica, sendo, a seguir, lavadas, drenadas, fatiadas, e as sementes retiradas e, então foram pesadas novamente. Os resultados foram apresentados em porcentagem do peso da matéria-prima pronta para o processamento, em relação ao peso original da matéria-prima. 
b) Textura: Foi determinada no "Texture Testing System" modelo TP-2, acoplado a uma registrador automático de variações de força, operando com célula-padrão de cisalhamento e compressão CS-1, com 10 lâminas de 1/8 polegada de espessura e ângulos de $90^{\circ}$. O instrumento estava provido de um anel de prova de $300 \mathrm{lbf}$ e a velocidade de descida do pistão foi de $20 \mathrm{~cm} / \mathrm{min}$.

As amostras foram anteriormente pesadas (50 gramas de fruta) e colocadas ao acaso na célula-teste. Os resultados foram expressos em Ibf/g de amostra.

Foram usadas para cada análise física 2 amostras (ou 2 repetições) tomadas aleatoriamente dos lotes dos dois tipos de matéria-prima (frutas doces e ácidas).

\subsubsection{Análises químicas}

a) pH: Foi determinado em potenciômetro Alphalab, modelo PA-200. Os resultados foram expressos em unidades de $\mathrm{pH}$.

b) Acidez total titulável: Foi determinada segundo método de referência número 22060 da AOAC (1975), conforme descrito a seguir: amostras de $10 \mathrm{~g}$ foram trituradas com $90 \mathrm{ml}$ de água destilada e, a seguir, tituladas rapidamente e sob agitação, com solução $0,1 \mathrm{~N}$ de $\mathrm{NaOH}$, até $\mathrm{pH} 7,0$; a partir deste ponto a titulação seguiu lentamente até $\mathrm{pH} 8,1$. Os resultados foram expressos em porcentagem do ácido presente em maior quantidade na matéria-prima, que no caso da carambola é o ácido oxálico.

c) Teor de sólidos solúveis: Foi determinado em refratômetro Atago, modelo $\mathrm{N}-1$. Os resultados foram expressos em ${ }^{\circ} \mathrm{Brix}$.

d) Teor de ácido ascórbico: Foi determinado por extração em ácido oxálico e 
titulação, segundo método de Tillmans modificado por Leme Júnior \& Malavolta (1950).

Amostras de $10 \mathrm{~g}$ foram trituradas em liqüidificador com $50 \mathrm{ml}$ de ácido oxálico $(0,4 \%)$, durante 3 minutos. A seguir, a mistura foi passada para um balão volumétrico de $100 \mathrm{ml}$. O copo do liqüidificador foi lavado com porções de aproximadamente $20 \mathrm{ml}$ de ácido oxálico $(0,4 \%)$, que eram adicionadas ao balão volumétrico de $100 \mathrm{ml}$, até completar o volume. O conteúdo do balão foi filtrado e $2 \mathrm{ml}$ deste foram pipetados para 1 erlenmeyer de $125 \mathrm{ml}$ e adicionado $50 \mathrm{ml}$ de água destilada, que a seguir foi titulado sob agitação, com solução corante de 2,6 - diclorofenolindofenol (Reativo de Tillmans). Os teores de ácido ascórbico das amostras foram calculados tomando-se por base um padrão de ácido ascórbico, previamente determinado. Os resultados foram expressos em $\mathrm{mg}$ de ácido ascórbico por $100 \mathrm{~g}$ de amostra.

As análises químicas foram efetuadas com 2 repetições em amostras tomadas aleatoriamente dos lotes dos dois tipos de matéria-prima (frutas doces e ácidas).

\subsection{Processamento}

A seqüência de operações utilizadas no processamento de carambola em calda está indicada na Figura 2.

Após o recebimento dos lotes de carambola no laboratório as frutas foram selecionadas, lavadas em água corrente, drenadas por 15 minutos, fatiadas transversalmente em pedaços com cerca de $0,5 \mathrm{~cm}$ de espessura, tendo em seguida as sementes retiradas.

\subsubsection{Tratamentos de pré-processamento}

Cada tipo de fruta foi submetido aos tratamentos que constam da Figura 3. 


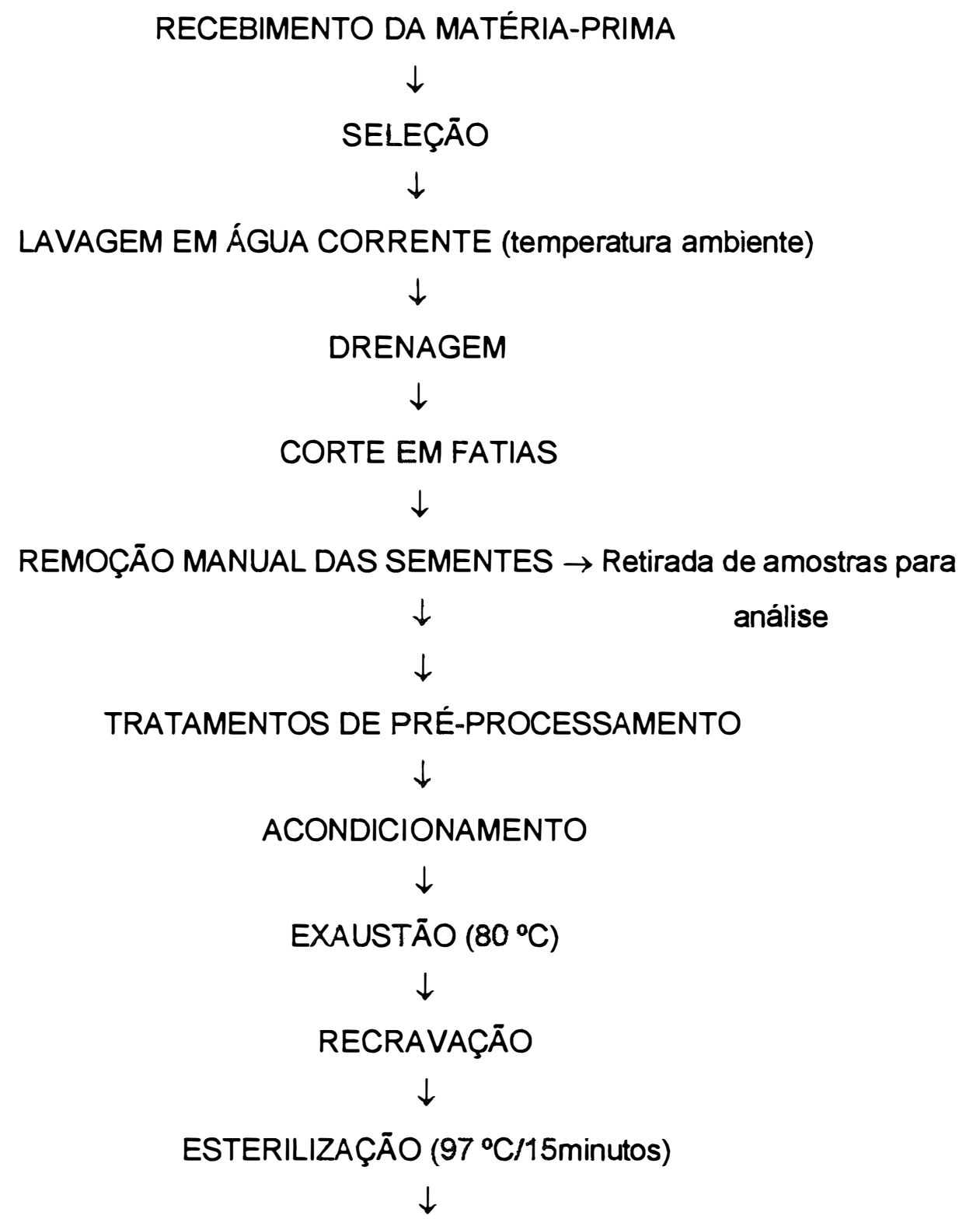

RESFRIAMENTO (tanque $d$ circulação de água à temperatura ambiente)

$\downarrow$

ARMAZENAMENTO À TEMPERATURA AMBIENTE

Figura 2 - Fluxograma das operações utilizadas no processamento das carambolas. 


\begin{tabular}{|c|c|c|c|c|c|}
\hline \multicolumn{3}{|c|}{ Sem adição de cloreto de cálcio (A) } & \multicolumn{3}{|c|}{ Com adição de cloreto de cálcio (B) } \\
\hline 1 & 2 & 3 & 4 & 5 & 6 \\
\hline Carambola & Caramboła & Carambola & Carambola & Carambola & Carambola \\
\hline+ & + & + & + & + & + \\
\hline Xarope de & Xarope de & Xarope de & Xarope de & Xarope de & Xarope de \\
\hline \multirow[t]{7}{*}{$\begin{array}{c}\text { Sacarose (220Brix } \\
\text { de equilibrio) }\end{array}$} & $\begin{array}{l}\text { Sacarose (25०Brix } \\
\text { de equilibrio) }\end{array}$ & $\begin{array}{c}\text { Sacarose ( } 28^{\circ} B r i x \\
\text { de equilibrio) }\end{array}$ & $\begin{array}{c}\text { Sacarose (220Brix } \\
\text { de equilibrio) }\end{array}$ & $\begin{array}{l}\text { Sacarose (25Brix } \\
\text { de equilibrio) }\end{array}$ & $\begin{array}{c}\text { Sacarose ( } 28^{\circ} B \text { rix } \\
\text { de equilibrio) }\end{array}$ \\
\hline & + & + & + & + & + \\
\hline & Pectina & Pectina & $\mathrm{CaCl}_{2}$ & Pectina & Pectina \\
\hline & & + & & + & + \\
\hline & & Ácido ascórbico & & $\mathrm{CaCl}_{2}$ & $\mathrm{CaCl}_{2}$ \\
\hline & & & & & + \\
\hline & & & & & Ácido ascórbico \\
\hline
\end{tabular}

Figura 3 - Esquema dos tratamentos de pré-processamento aos quais as frutas de cada tipo de carambola foram submetidas.

\section{A. Tratamentos sem adição de cloreto de cálcio}

\section{Carambola + xarope de sacarose}

Depois de lavadas, drenadas, e fatiadas, as frutas foram acondicionadas em latas, previamente limpas, juntamente com um xarope de sacarose (pré-aquecido) preparado de forma a obter $22^{\circ}$ Brix de equilibrio na conserva (considerando o teor de sólidos solúveis da fruta).

\section{Carambola + xarope de sacarose + pectina}

Este tratamento seguiu o mesmo procedimento do anterior (A.1.), porém foi utilizado xarope com concentração para se obter $25^{\circ} \mathrm{Brix}$ de equilíbrio na conserva (considerando o teor de sólidos solúveis da fruta). Foi também adicionada $0,1 \%$ de pectina em relação ao peso das frutas. A pectina foi misturada ao açúcar utilizado para a elaboração do xarope, a fim de não formar 
grumos. A legislação brasileira não estabelece para este aditivo um limite máximo de adição do mesmo em conservas de frutas (Brasil, 1988).

\section{Carambola + xarope de sacarose + pectina + ácido ascórbico}

Este tratamento seguiu o mesmo procedimento que o primeiro (A.1.), no entanto, o xarope foi preparado a fim de se obter $28^{\circ} \mathrm{Brix}$ de equilíbrio na conserva (considerando o teor de sólidos solúveis da fruta). Foram também adicionados $0,2 \%$ de pectina e, $300 \mathrm{mg}$ de ácido ascórbico $/ \mathrm{kg}$ de fruta, conforme a legislação brasileira estabelece para este aditivo (Brasil, 1988).

\section{B. Tratamentos com adição de cloreto de cálcio}

\section{Carambola + xarope de sacarose $+\mathrm{CaCl}_{2}$}

Este tratamento seguiu o mesmo procedimento do primeiro (A.1.), com adição de cloreto de cálcio ao xarope de sacarose, na proporção de 0,1\% em relação ao peso das frutas, sendo que, para este tipo de conserva de frutas não há um limite máximo estabelecido pela legislação brasileira.

\section{Carambola + xarope de sacarose + pectina $+\mathrm{CaCl}_{2}$}

Este tratamento seguiu o mesmo procedimento do segundo (A.2.), com adição ao xarope de sacarose de $0,2 \%$ de cloreto de cálcio em relação ao peso das frutas.

\section{Carambola + xarope de sacarose + pectina + ácido ascórbico $+\mathrm{CaCl}_{2}$}

Este tratamento seguiu o mesmo procedimento do terceiro (A.3.), com adição ao xarope de cloreto de cálcio na proporção de 0,4\% em relação ao peso das frutas. 


\subsubsection{Acondicionamento}

$\mathrm{O}$ acondicionamento foi feito em latas de folha-de-flandres, com capacidade para $800 \mathrm{~g}$ de produto $(99,5 \times 118 \mathrm{~mm})$, revestidas internamente com verniz epóxi, próprias para produtos ácidos. Em cada lata foram colocados $330 \mathrm{~g}$ de carambola, preenchendo o volume do recipiente com xarope de sacarose em concentraçōes distintas (espaço livre de $5 \mathrm{~mm}$ ).

\subsubsection{Exaustão e recravação}

Foi feita a exaustão por imersão (parcial) das latas em água à ebulição $\left(97^{\circ} \mathrm{C}\right)$, até que o centro geométrico dos recipientes atingisse $80^{\circ} \mathrm{C}$. A seguir as latas foram imediatamente recravadas.

\subsubsection{Esterilização e resfriamento}

A esterilização foi feita por imersão (total) das latas em água à ebulição $\left(97^{\circ} \mathrm{C}\right)$ durante 15 minutos e, a seguir, resfriadas em tanque com circulação de água fria (água corrente).

\subsubsection{Armazenamento}

Após resfriamento, as latas foram armazenadas à temperatura ambiente.

\subsection{Avaliação do produto processado}

Análises físicas, químicas e sensoriais foram realizadas a fim de avaliar a qualidade das carambolas termicamente processadas e determinar qual tipo de fruta melhor se adaptou ao processamento, e a eficiência dos tratamentos. As análises físicas e químicas foram efetuadas aos $30,60,90$, 120, 150 e 180 dias após o processamento, e as análises sensoriais aos 0,30, $60,90,120,150$ e 180 dias. 


\subsubsection{Análises físicas}

a) Textura: para a determinação da textura das frutas foi utilizado o "Texture Testing System", conforme descrito no item 4.2.1.a.

b) Vácuo: Foi determinado o vácuo das latas com o auxílio do Vacuômetro "Marshalltown", em polegadas de mercúrio (pol.Hg).

c) Peso bruto: Foi utilizada uma balança semi-analítica para a determinação do peso bruto (peso da embalagem mais o peso do produto).

d) Peso drenado: Foi determinado com um conjunto constituido de peneira US-Tyler $n^{\circ} 8$ (abertura de malha de $2,38 \mathrm{~mm}$ ) e fundo. Todo conteúdo da lata foi vertido no conjunto peneira-fundo, inclinando-se ligeiramente a peneira (ângulo de $45^{\circ}$ ) sobre o fundo e deixando-se drenar durante dois minutos. $O$ peso da peneira mais o peso do produto menos 0 da peneira, constitui o peso drenado.

\subsubsection{Análises químicas}

a) pH: conforme descrito no item 4.2.2.a. por medição direta no xarope do produto.

b) Acidez total titulável: conforme descrito no item 4.2.2.b. por mediçāo direta no xarope do produto.

c) Teor de sólidos solúveis: conforme descrito no item 4.2.2.c., utilizando o xarope do produto.

d) Teor de ácido ascórbico: conforme descrito no item 4.2.2.d., utilizando o xarope do produto.

\subsubsection{Análise sensorial}

As amostras dos lotes dos dois tipos da fruta (doce e ácido) foram avaliadas subjetivamente quanto à cor, textura e sabor.

As avaliaçōes das amostras foram feitas por uma equipe de 8 
provadores, previamente selecionados e instruídos para este tipo de avaliação, considerando o fato de se constituir em um produto ainda não existente no mercado. Para estas avaliações utilizou-se uma escala numérica estruturada de nove pontos (Martin, 1973); os modelos de fichas utilizados nestas avaliações estão representados nas Figuras 4,5 e 6 . Os parâmetros dos atributos foram definidos aos provadores, fornecendo-Ihes uma tabela contendo todas essas definições (Tabela 2).

Para avaliação da cor das frutas, juntamente com um copo de água, as amostras foram servidas em pratos plásticos brancos dispostos aleatoriamente em bandeja de alumínio, colocada em local com iluminação de luz fluorescente. Os pratos foram codificados com números aleatórios compostos de três dígitos.

Para avaliação da textura e do sabor das frutas, as amostras foram servidas em pratos plásticos brancos dispostos aleatoriamente em bandeja de alumínio, colocada em cabines individuais com iluminação vermelha para mascarar a cor da fruta, havendo também na bandeja um copo de água. Os pratos foram codificados com números aleatórios compostos de três dígitos.

Todas as avaliações foram feitas com duas repetições, de forma que cada provador avaliasse a mesma amostra duas vezes (em sessões diferentes).

\subsubsection{Análise estatística dos resultados}

\section{a) Matéria-prima}

Os dados levantados nas análises da matéria-prima foram apresentados através de médias com os respectivos erros padrão da média, correspondente a duas repetições.

\section{b) Produto processado}

Os dados do produto processado foram analisados através do 
delineamento em blocos casualizados (DBC) com seis tratamentos e duas repetições para cada tipo de fruta testada, com utilização do teste de Tukey ao nivel de $5 \%$ de significância (Gomes, 1973).

As médias obtidas na avaliação sensorial foram analisadas através do DBC com seis tratamentos e 16 repetições para cada tipo de fruta, com utilização do teste de Tukey ao nivel de $5 \%$ de significância.

AVALIAÇÃO SENSORIAL - TEXTURA

Produto: CARAMBOLA EM CALDA

Nome:

Data:

Por favor, prove as amostras e indique a intensidade da textura de acordo com a escala abaixo:

\begin{tabular}{|c|c|c|c|c|c|}
\hline AMOSTRAS & $\begin{array}{c}\text { MUITO MOLE } \\
1 \\
\end{array}$ & $\begin{array}{l}\text { MOLE } \\
2 \quad 3\end{array}$ & $\begin{array}{ccc}\text { NEM MOLE NEM FIRME } \\
4 & 5 & 6 \\
\end{array}$ & $\begin{array}{l}\text { FIRME } \\
7 \begin{array}{r}7 \\
\end{array}\end{array}$ & $\begin{array}{c}\text { MUITO FIRME } \\
9 \\
\end{array}$ \\
\hline & & & & & \\
\hline & & & & & \\
\hline & & & & & \\
\hline
\end{tabular}

Comentários:

Figura 4. Modelo de ficha utilizado na avaliação sensorial das amostras quanto à textura.

\section{AVALIAÇÃO SENSORIAL - SABOR}

Produto: CARAMBOLA EM CALDA

Nome: Data:

Por favor, prove as amostras e indique a intensidade do sabor de acordo com a escala abaixo:

\begin{tabular}{|c|c|c|c|c|c|}
\hline AMOSTRAS & $\begin{array}{c}\text { SEM } \\
\text { SABOR } \\
1 \\
\end{array}$ & $\begin{array}{l}\text { SABOR } \\
\text { FRACO } \\
2 \quad 3 \\
\end{array}$ & \begin{tabular}{ccc}
\multicolumn{3}{c}{ SABOR } \\
MODERADO \\
4 \\
$4 \quad 5 \quad 6$
\end{tabular} & $\begin{array}{c}\text { SABOR } \\
\text { INTENSO } \\
7 \quad 8 \\
\end{array}$ & $\begin{array}{c}\text { SABOR MUITO } \\
\text { INTENSO } \\
9 \\
\end{array}$ \\
\hline & & & & & \\
\hline & & & & & \\
\hline & & & & & \\
\hline
\end{tabular}

Comentários:

Figura 5. Modelo de ficha utilizado na avaliação sensorial das amostras quanto ao sabor. 


\section{AVALIAÇÃO SENSORIAL - COR}

Produto: CARAMBOLA EM CALDA

Nome:

Data:

Por favor, observe as amostras e indique a intensidade da cor de acordo com a escala abaixo:

\begin{tabular}{|c|c|c|c|c|c|}
\hline AMOSTRAS & $\begin{array}{l}\text { SEM } \\
\text { COR }\end{array}$ & $\begin{array}{l}\text { COR } \\
\text { FRACA }\end{array}$ & $\begin{array}{c}\text { COR } \\
\text { MODERADA }\end{array}$ & $\begin{array}{c}\text { COR } \\
\text { INTENSA }\end{array}$ & $\begin{array}{c}\text { COR MUITO INTENSA } \\
9\end{array}$ \\
\hline & 1 & & 5 & $\begin{array}{l}7 \\
\end{array}$ & \\
\hline & & & & & \\
\hline & & & & & \\
\hline
\end{tabular}

Comentários:

Figura 6. Modelo de ficha utilizado na avaliação sensorial das amostras quanto à cor.

Tabela 2. Definição dos parâmetros dos atributos da análise sensorial.

\begin{tabular}{|l|l|l|}
\hline Textura & Muito mole & Quando a fruta está desintegrada \\
\hline & Mole & Com textura branda mas não desintegrada \\
\hline & Nem mole nem firme & Com textura intermediária (entre mole e firme) \\
\hline & Firme & Com textura fime mas não "crocante" \\
\hline Sabor & Sem sabor & Com textura "crocante" \\
\hline & Sabor fraco & Isenta de sabor da fruta \\
\hline & Sabor moderado & Com sabor levemente da fruta \\
\hline & Sabor intenso & Com babtante sabor da fruta \\
\hline Cor & Sabor muito intenso & Com intenso sabor da fruta \\
\hline & Sem cor & Com cor esbranquiçada \\
\hline & Cor fraca & Com cor levemente amarela \\
\hline & Cor moderada & Com cor amarela \\
\hline & Cor intensa & Com cor intensamente amarela \\
\hline & Cor muito intensa & Com cor tendendo ao alaranjado \\
\hline
\end{tabular}




\section{RESULTADOS E DISCUSSÄO}

\subsection{Caracterizaçăo da matéria-prima}

\subsubsection{Análises físicas}

$\mathrm{Na}$ Tabela 3, são apresentados os resultados das análises dos atributos físicos.

Tabela 3. Características físicas da matéria-prima.

\begin{tabular}{l|c|c}
\hline \multicolumn{1}{c|}{ Análises } & Tipo Doce & Tipo Ácido \\
\hline Textura (lbf/g) & $3,44 \pm 0,220$ & $3,31 \pm 0,290$ \\
Rendimento (\%) & $84,20 \pm 0,640$ & $85,46 \pm 0,245$ \\
\hline
\end{tabular}

Pela Tabela 3, verifica-se que as frutas do tipo doce apresentaram textura mais firme (3,44 lbf/g) que as do tipo ácido (3,31 lbf/g); no entanto, com relaçāo ao rendimento, o resultado foi inferior $(84,20 \%)$ quando comparado com o do tipo ácido $(85,46 \%)$.

O rendimento é um parâmetro que a indústria de alimentos utiliza para avaliar a qualidade da matéria-prima. $O$ rendimento dos dois tipos de fruta de carambola não diferiram muito entre si: para cada $1000 \mathrm{~g}$ de carambola "in natura" $842 \mathrm{~g}$ do tipo doce e $854,6 \mathrm{~g}$ do tipo ácido foram utilizadas para o processamento. Tais resultados representam qualidade e bom aproveitamento da matéria-prima, ou seja, pequena presença de frutas amassadas e/ou deterioradas por microrganismos ou insetos.

\subsubsection{Análises químicas}

Os teores de ácido ascórbico, acidez total titulável, sólidos 
solúveis e o valor do pH da matéria-prima estão apresentados na Tabela 4.

Tabela 4. Características químicas da matéria-prima.

\begin{tabular}{l|c|c}
\hline \multicolumn{1}{c|}{ Análises } & Tipo Doce & Tipo Ácida \\
\hline Vitamina C (mg/100g) & $44,28 \pm 1,425$ & $42,86 \pm 0$ \\
pH & $4,01 \pm 0,095$ & $2,52 \pm 0,055$ \\
Acidez total titulável (\% ác. oxálico) & $0,10 \pm 0,002$ & $0,31 \pm 0,005$ \\
Teor de sólidos solúveis ('Brix) & $8,25 \pm 0,250$ & $7,75 \pm 0,250$ \\
\hline
\end{tabular}

Os teores de vitamina $\mathrm{C}$ relativos aos dois tipos de fruta estudados são superiores ao obtido por Oliveira et al. (1989) que encontraram $17,16 \mathrm{mg} / 100 \mathrm{~g}$ em frutas de carambola cujo tipo não foi especificado pelos autores.

Comparando os dados da Tabela 4 verifica-se que o tipo doce é mais rico em vitamina $C$ que o ácido.

Os valores de $\mathrm{pH}$ obtidos foram muito semelhantes aos encontrados por Joseph \& Mendonca (1989a): 2,40 para o tipo ácido e 4,00 para o tipo doce. Já, Oliveira et al. (1989) encontraram um valor intermediário de 3,33 (Tabela 1), porém não especificando o tipo de fruta estudado.

O teor de sólidos solúveis é um importante parâmetro, já que indica a quantidade, em gramas, de sólidos que se encontram dissolvidos no produto, podendo ser usado para avaliar o grau de doçura, uma vez que, o teor de açúcares normalmente constitui 65 a $85 \%$ do teor de sólidos solúveis totais (Chitarra \& Chitarra, 1990).

Os valores de sólidos solúveis encontrados para as frutas doce e ácida foram, relativamente elevados. O resultado obtido para o tipo doce é semelhante ao que foi citado por Joseph \& Mendonca (1989a) que encontraram valores entre 6,0 e 8,4 ${ }^{\circ} \mathrm{Brix}$; no entanto, em relação ao tipo ácido o resultado obtido foi superior aos citados por tais autores, que encontraram valores entre 
3,4 e 5,0 ${ }^{\circ}$ Brix. Os resultados foram também superiores aos obtidos por Oliveira et al. (1989), que encontraram 5, ${ }^{\circ} \mathrm{Brix}$ (Tabela 1 ), porém não especificando o tipo de fruta estudado.

Os tipos de fruta analisados, doce e ácido, apresentaram valores de acidez total titulável ( $\mathrm{g}$ de ácido oxálico/100g de amostra) distintos, sendo o do tipo ácido superior. Para o tipo doce, o resultado foi semelhante ao que foi citado por Joseph \& Mendonca (1989a); no entanto, em relação ao tipo ácido o resultado encontrado foi inferior aos citados por tais autores, que relataram valores entre 0,57 e 0,63\%. Oliveira et al. (1989) obtiveram 0,37g de ácido cítrico/100g de amostra (Tabela 1), porém não especificando o tipo de fruta estudado.

\subsection{Caracterização do produto final}

\subsubsection{Análises físicas}

As determinações de peso bruto e peso drenado das latas (Tabelas 5 e 6 , respectivamente), nos períodos de 30 a 180 dias de armazenamento, mostraram resultados com algumas diferenças significativas em relação às épocas de avaliação e, principalmente, em relação aos tratamentos.

Essa variação embora indesejável em qualquer tipo de processamento de alimentos, não prejudicou a qualidade do produto. $O$ peso bruto é importante para o armazenamento e transporte do produto e não vem expresso nos rótulos dos recipientes. As variaçōes observadas neste atributo podem ter ocorrido devido à variação de peso das latas utilizadas, bem como pela absorção de sacarose pelas frutas durante a estocagem.

O peso drenado deve obrigatoriamente constar dos rótulos dos recipientes de frutas em calda e é um importante fator utilizado pelas indústrias para o controle desses produtos. As variações observadas podem também ser 
explicadas pela absorção de parte do xarope pelas frutas, principalmente no decorrer do armazenamento.

Resultados sem variaçōes significativas foram encontrados por Richards (1996) na elaboração de morango em calda.

Com relação ao vácuo (Tabela 7) observa-se que para o tipo doce, os tratamentos 2 e 6 não diferiram entre si e dos tratamentos 1 e 3 , mas diferiram significativamente do tratamento 5 , que, por sua vez, não diferiu de 4. Para o tipo ácido, os tratamentos 1 e 5 diferiram entre si, mas não dos demais. No que diz respeito às épocas de avaliação, para o tipo ácido não ocorreram variações significativas na medida do vácuo, mas para o tipo doce sim. No entanto, todos os valores encontrados estão de acordo com o que é recomendado para produtos enlatados, ou seja, vácuo acima de 10 pol. Hg não diferiu do tratamento 2 .

(Jackix, s.d.). O autor ainda cita que a legislação brasileira exige para frutas em calda, $11 \mathrm{pol} . \mathrm{Hg}(300 \mathrm{~mm} \mathrm{Hg})$.

Vácuo é o termo usado para indicar a diferença entre a pressão atmosférica do local e a pressão interna do recipiente, sendo portanto uma medida da quantidade de ar eliminado. Desta forma a medida do vácuo é muito importante, uma vez que, a presença de oxigênio pode tanto desencadear reações oxidativas (deterioração de ácido ascórbico e escurecimento), como também possibilitar a proliferação microbiana, dependendo do tipo de produto processado. A temperatura de exaustão e o volume do espaço livre estão diretamente relacionados com o vácuo produzido, ou seja, quanto maior a temperatura de exaustão, maior será o vácuo, e, por outro lado, quanto maior o espaço livre, menor será o vácuo (Jackix, s.d.).

Com relação à textura, o tipo doce apresentou resultados maiores que o tipo ácido (Tabela 8). Observa-se que para as frutas doces, o tratamento 6 (maior valor encontrado) diferiu significativamente dos demais, já que, neste caso, o xarope foi adicionado de $0,2 \%$ de pectina e $0,4 \%$ de $\mathrm{CaCl}_{2}$ em relação ao peso da fruta. Ainda para este tipo de fruta, o menor valor de textura foi 

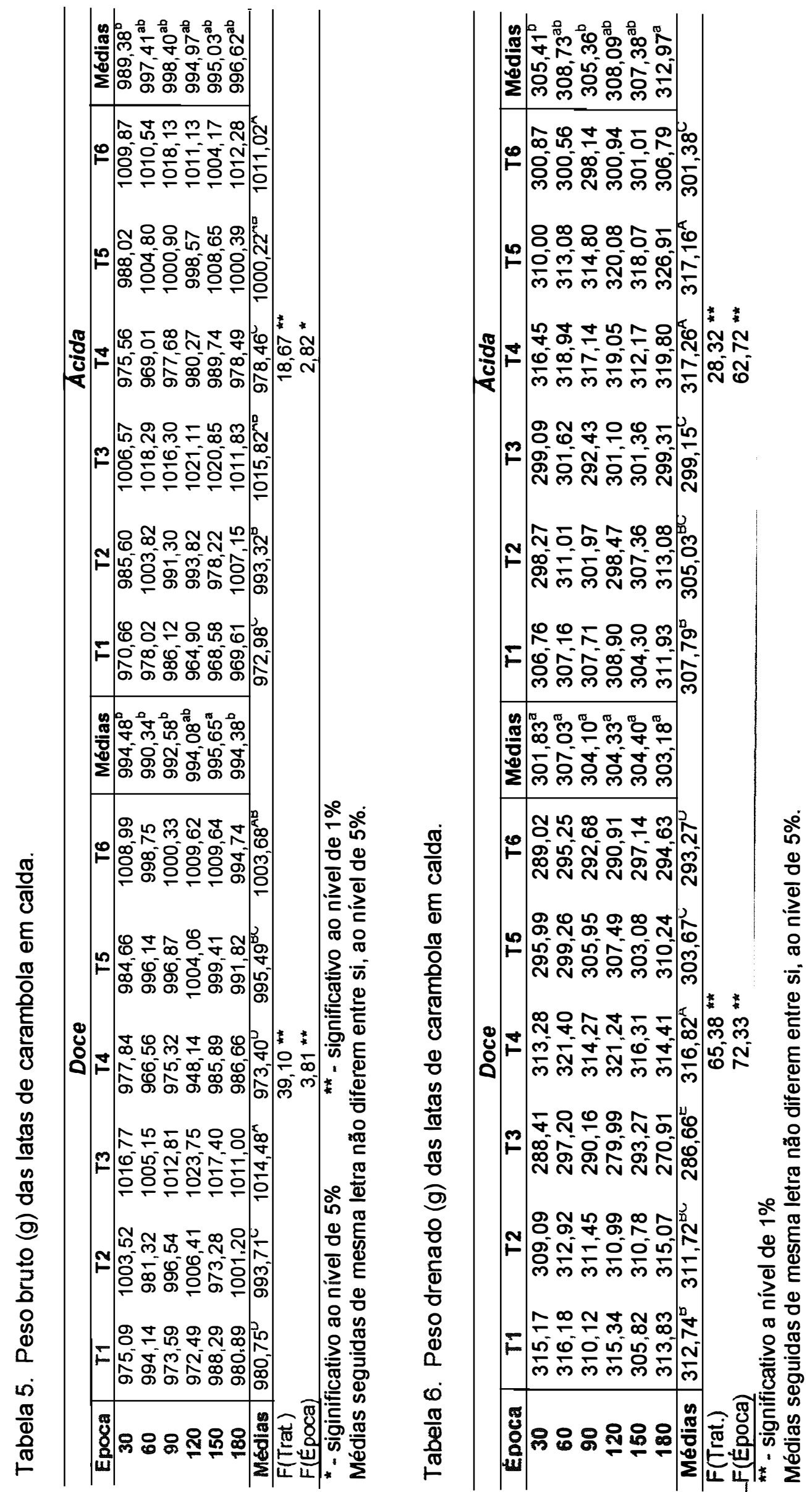
encontrado para o tratamento 1, já que se trata da testemunha; o mesmo, só não diferiu do tratamento 2 .

Em relação às frutas ácidas, as observaçōes foram bem diferentes: o maior valor de textura foi encontrado para o tratamento 2 (adição ao xarope de $0,1 \%$ de pectina em relação ao peso da fruta) que diferiu estatisticamente dos demais, e os menores valores para os tratamentos 4 e 5 (adição de $0,1 \%$ de $\mathrm{CaCl}_{2}$ e, $0,1 \%$ de pectina $+0,2 \%$ de $\mathrm{CaCl}_{2}$, respectivamente). Tais resultados mostram que o cálcio não foi muito efetivo para preservar a textura nas frutas ácidas processadas, como o que foi observado por Richards (1996) em morango em calda.

Estes resultados podem ser explicados pela alta acidez da fruta, ou seja, a acidificação da parede celular e da lamela média pode promover a substituição do $\mathrm{Ca}^{2+}$ pelo $\mathrm{H}^{+}$, e conseqüentemente, o enfraquecimento das ligações e da coesão existente entre as cadeias de pectina da parede celular e da lamela média (Awad, 1993).

De maneira geral, para os dois tipos de fruta houve incremento da textura até os 90 dias de armazenamento, mantendo-se em seguida praticamente a mesma até os 180 dias de estocagem. Esses resultados podem ser observados nas Figuras 7 e 8.

Comparando-se os valores das tabelas 3 e 8 para os dois tipos de fruta, observa-se que a textura da fruta "in natura" é bem maior que a da fruta processada pelo calor, mostrando realmente que a temperatura tem um efeito drástico sobre este parâmetro. O mesmo foi observado por Richards (1996) trabalhando com morango em calda.

\subsubsection{Análises químicas}

Os resultados das avaliações de pH, ácido ascórbico, acidez total titulável, e sólidos solúveis do produto processado são apresentados nas Tabelas 9, 10, 11 e 12. 

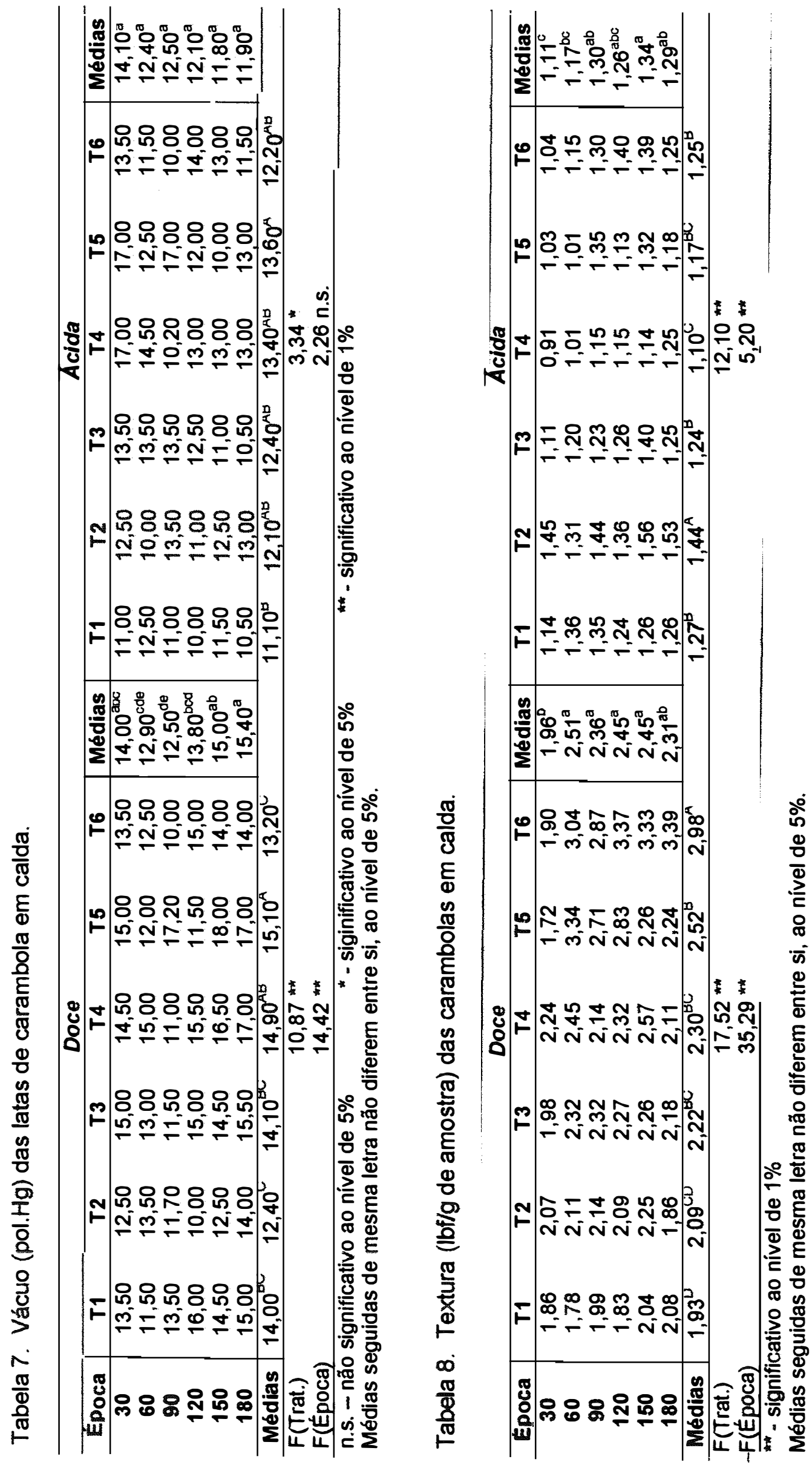


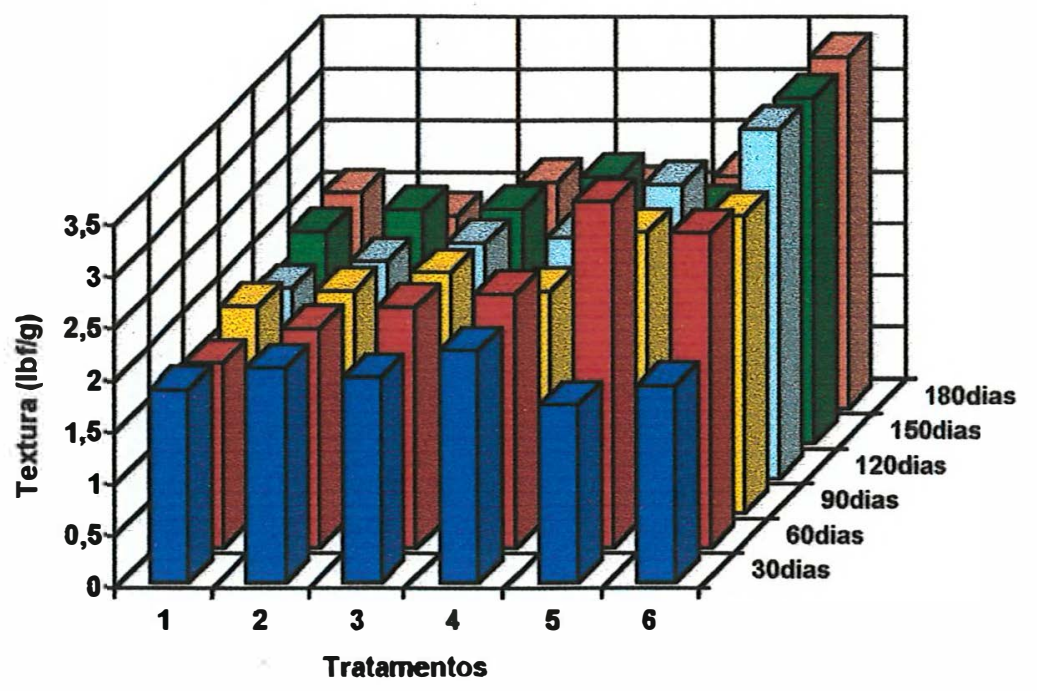

Figura 7. Variação da textura em função dos tratamentos e períodos de armazenamento - Tipo Doce.

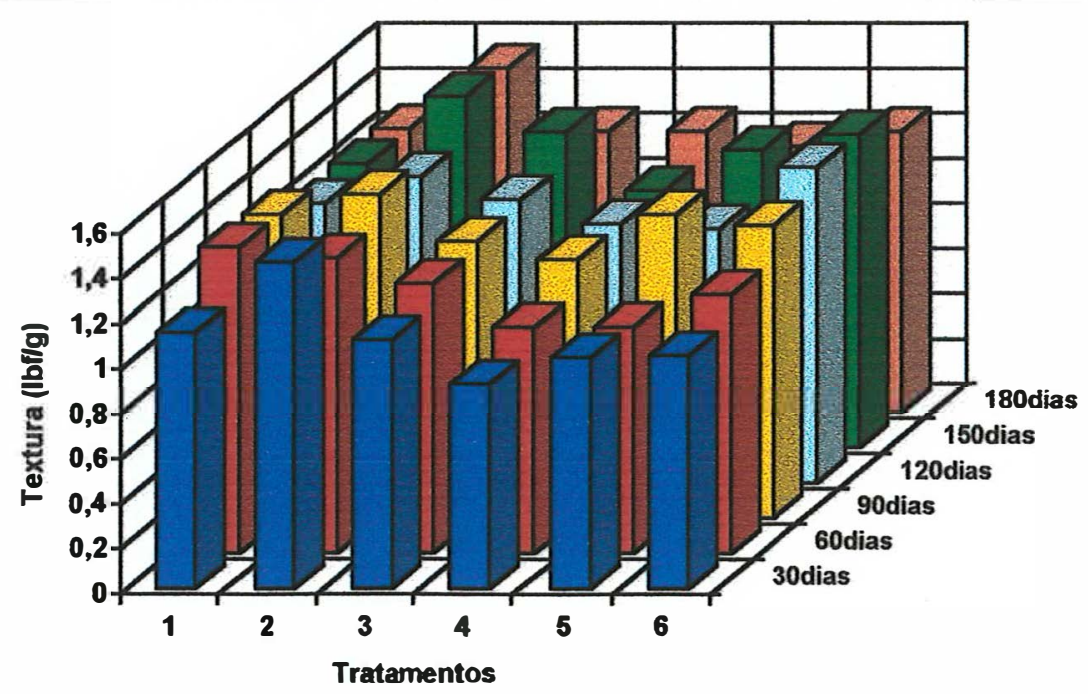

Figura 8. Variação da textura em função dos tratamentos e periodos de armazenamento - Tipo Ácido. 
Quanto ao parâmetro pH (Tabela 9), para o tipo doce, aos 30 e 60 dias os valores não diferiram entre si mas em relação às outras épocas de avaliação, e para o tipo ácido, tais diferenças não foram observadas.

Comparando-se os tratamentos, para o tipo doce verifica-se que $o$ tratamento 6 foi o de menor valor, diferindo dos demais; o tratamento 1 foi o de maior valor, não diferindo do tratamento 2, mas sim dos demais. Já, para o tipo ácido, os tratamentos 1, 2 e 3 apresentaram os maiores valores, diferindo dos demais porém não entre si; os menores resultados foram obtidos nos tratamentos 5 e 6 , que também não diferiram entre si, mas dos demais. 0 tratamento 4 ficou com um valor intermediário, diferindo significativamente dos outros.

Comparando-se os valores de $\mathrm{pH}$ da matéria-prima (Tabela 4) com os resultados do produto final (Tabela 9), observa-se que os valores de $\mathrm{pH}$ da fruta "in natura", tanto doce como ácida, foram superiores aos das processadas. Já, Richards (1996) encontrou valores semelhantes entre matériaprima e produto processado (morango em calda) durante todo o período de armazenamento do mesmo.

A Tabela 10 mostra os teores de ácido ascórbico dos produtos processados. Observa-se que para 0 tipo doce os tratamentos 3 e 6 foram superiores aos demais, diferindo dos mesmos, mas não entre si, e isto pode ser justificado pela adição de vitamina $C$ ao xarope desses tratamentos; o menor valor foi observado no tratamento 1 já que se trata da testemunha. Os tratamentos 3 e 6 também foram superiores aos demais, no caso do tipo ácido, pelo mesmo motivo anteriormente citado; os mesmos diferiram entre si e dos demais.

Com relação aos teores de vitamina $C$ ao longo do período de armazenamento, pode-se observar que para os dois tipos de fruta, houve um decréscimo nos valores: perdas de $36,80 \%$ para o tipo doce e $29,88 \%$ para o tipo ácido. Tal fato também foi observado por Novaes (1997), na elaboração de néctares comum e dietético de morango, por Sivieri (1997) em geléias comum e 
dietética de morango, e por Richards (1996) em morango em calda. Tais observações podem ser constatadas pelas Figuras 9 e 10.

Esta redução no teor de ácido ascórbico pode ser explicada pela oxidação deste componente durante o armazenamento. $O$ calor acelera esta oxidação especialmente quando o alimento está em contato com cobre, ferro ou enzimas oxidativas (Sturion et al., 1991).

Salomón et al. (1977) afirmam que perdas de ácido ascórbico são comuns em produtos, de uma forma geral, armazenados a temperatura ambiente, por períodos prolongados. Eleutério (1998) observou em geléia de acerola perda de $15,66 \%$ de ácido ascórbico após o processamento, e 13,76\% de redução deste conteúdo após 6 meses de armazenamento.

Mesmo assim, os valores obtidos ao final dos 180 dias de estocagem foram relativamente bons $(32,91 \mathrm{mg} / 100 \mathrm{~g}$ para o tipo doce $\mathrm{e}$ $36,49 \mathrm{mg} / 100 \mathrm{~g}$ para o tipo ácido). Comparando-se os valores dos dois tipos de fruta, pode-se observar também que as frutas ácidas apresentaram teores mais elevados de vitamina $C$ que as frutas doces.

Quanto à acidez total titulável (Tabela 11), para os dois tipos de fruta, a partir dos 30 dias de armazenamento, houve um decréscimo nos valores da acidez, fato que pode ser explicado pela redução no teor de ácido ascórbico, já que o mesmo é um dos componentes da acidez total titulável. Este fato foi também observado por Novaes (1997), Richards (1996) e Sivieri (1997).

Quanto aos tratamentos, para o tipo doce, o tratamento 6 foi o de maior valor, não diferindo apenas do 3 e 5; menor resultado foi obtido para o tratamento 1 , que diferiu significativamente dos demais. No caso das frutas ácidas, o tratamento 6 também foi superior, não diferindo apenas do 5; os menores dados foram encontrados para 1 e 2, que não diferiram entre si e do tratamento 3 .

O teor de sólidos solúveis totais (Tabela 12), no que diz respeito aos tratamentos, foi o esperado para os dois tipos de fruta, já que os xaropes foram preparados a fim de se obter determinadas concentrações de equilíbrio 

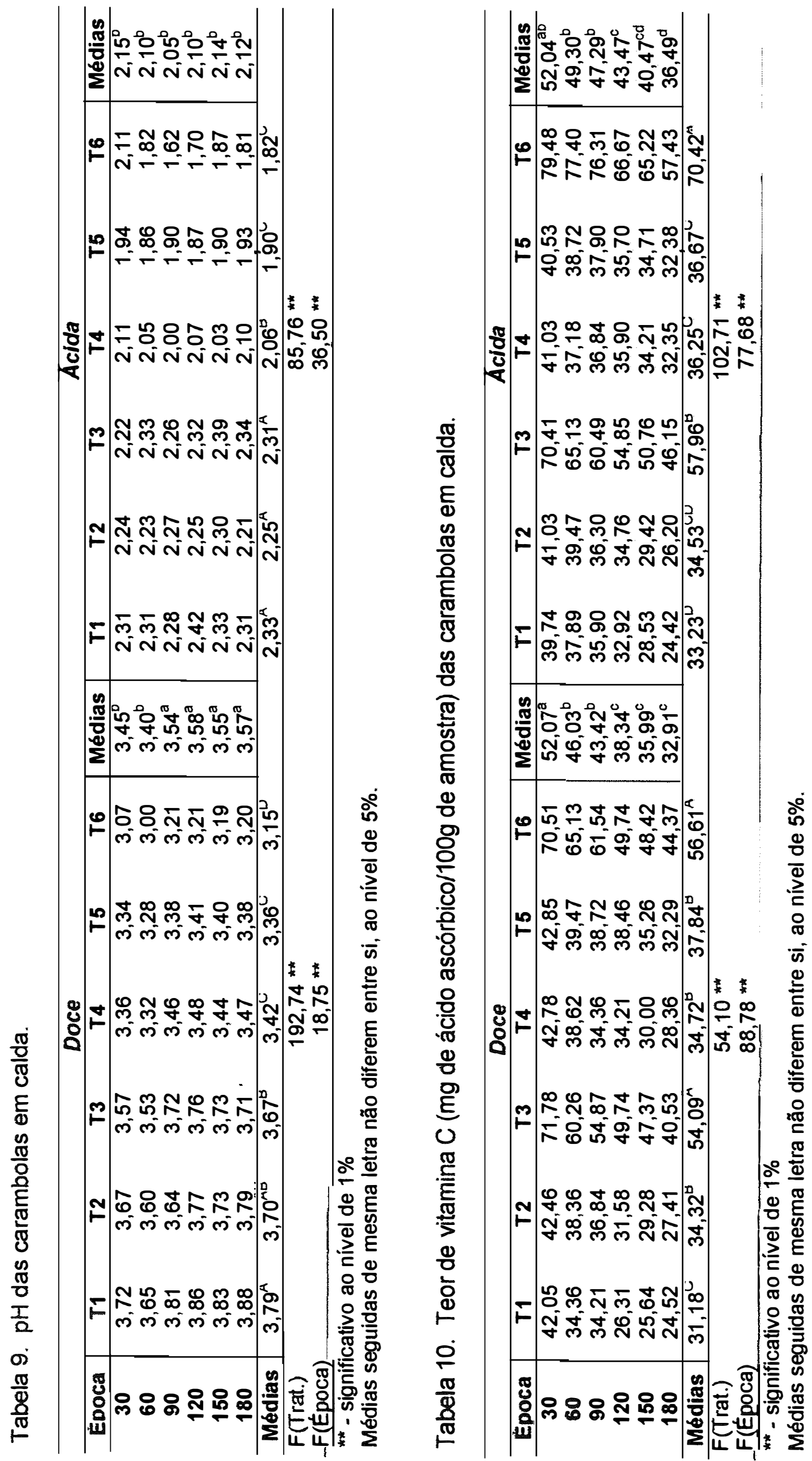


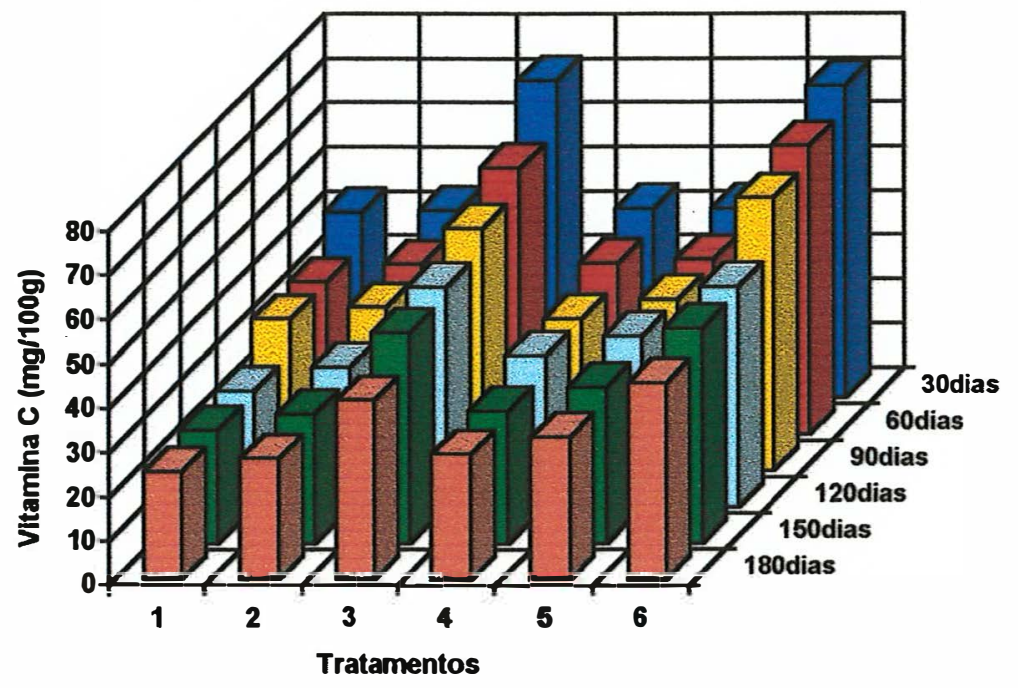

Figura 9. Variação do teor de vitamina $\mathrm{C}$ em função dos tratamentos e períodos de armazenamento - Tipo Doce.

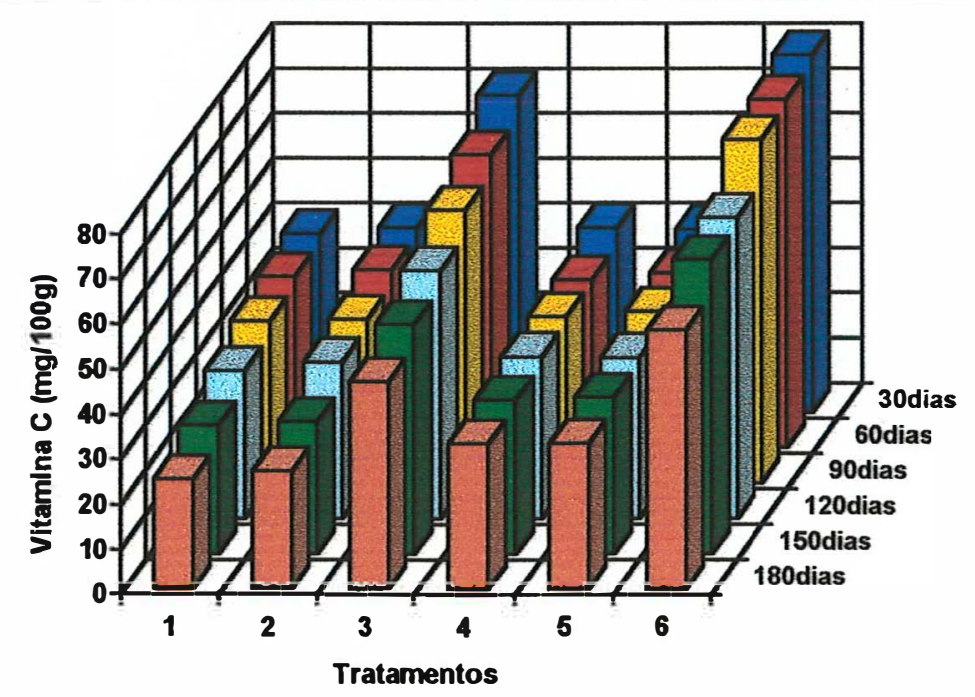

Figura 10. Variação do teor de vitamina $\mathrm{C}$ em função dos tratamentos e períodos de armazenamento - Tipo Ácido. 
na conserva, $22^{\circ}$ Brix para os tratamentos 1 e $4,25^{\circ}$ Brix para 2 e 5 , e $28^{\circ}$ Brix para 3 e 6; isto mostra que o preparo dos produtos foi feito de forma adequada.

\subsubsection{Análise sensorial}

As Tabelas $13,14,15$ e 16 apresentam os resultados das avaliações de textura, sabor e cor das carambolas em calda.

Quanto à textura (Tabela 13), para o tipo doce maiores resultados foram obtidos aos 30, 60 e 90 dias de armazenamento, e para o tipo ácido aos 0, 30 e 60 dias de armazenamento. Comparando-se os tratamentos, para as frutas doces não houve diferença significativa entre eles, embora o tratamento 4 (fruta + xarope $22{ }^{\circ}$ Brix $+0,1 \%$ de $\mathrm{CaCl}_{2}$ ) tenha apresentado maior nota. Já, para o tipo ácido, a maior nota foi observada no tratamento 2 (fruta + xarope $25^{\circ}$ Brix $+0,1 \%$ de pectina) que não diferiu do 3 , e sim dos demais. Neste caso, o tratamento 6 apresentou menor nota, embora não tenha diferido de 1, 4 e 5 .

Quanto ao sabor (Tabela 14), para o tipo doce maiores resultados foram obtidos a partir dos 90 dias de armazenamento, e para o tipo ácido a maior nota foi obtida aos 30 dias de armazenamento, sendo esta diferente estatisticamente das demais. Em relação aos tratamentos, para o tipo doce, o tratamento 6 (fruta + xarope $28{ }^{\circ} \mathrm{Brix}+0,2 \%$ de pectina $+0,4 \%$ de $\mathrm{CaCl}_{2}+$ $300 \mathrm{mg}$ de ácido ascórbico/kg de fruta) foi o que se destacou, diferindo significativamente dos demais; as menores notas foram observadas nos tratamentos 1 e 4, que não diferiram entre si, mas dos demais. Para o tipo ácido, a maior nota foi observada no tratamento 3 (fruta + xarope $28^{\circ} \mathrm{Brix}+$ $0,2 \%$ de pectina $+300 \mathrm{mg}$ de ácido ascórbico/ $\mathrm{kg}$ de fruta) que não diferiu de 2 e 6 , e sim dos demais; valores inferiores também foram obtidos nos tratamentos 1 e 4, que não diferiram entre si e nem do tratamento 5 .

Com relação à cor (Tabela 15), para o tipo doce não ocorreram diferenças significativas entre as épocas de avaliação do produto. Já, para o tipo ácido a maior nota foi observada aos 150 dias de armazenamento, embora esta não tenha diferido daquelas obtidas aos 30, 60, 90 e 120 dias; a pior nota 

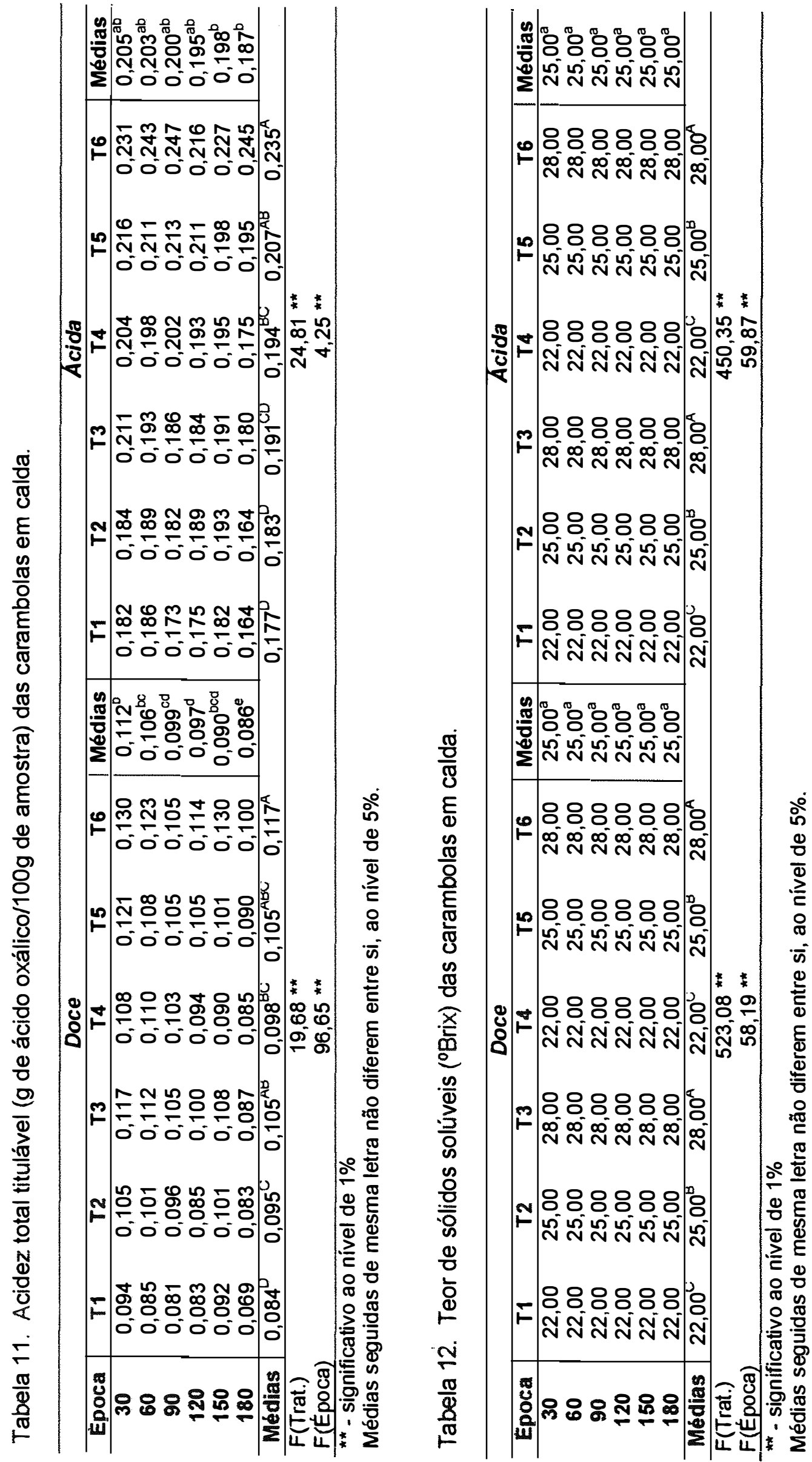

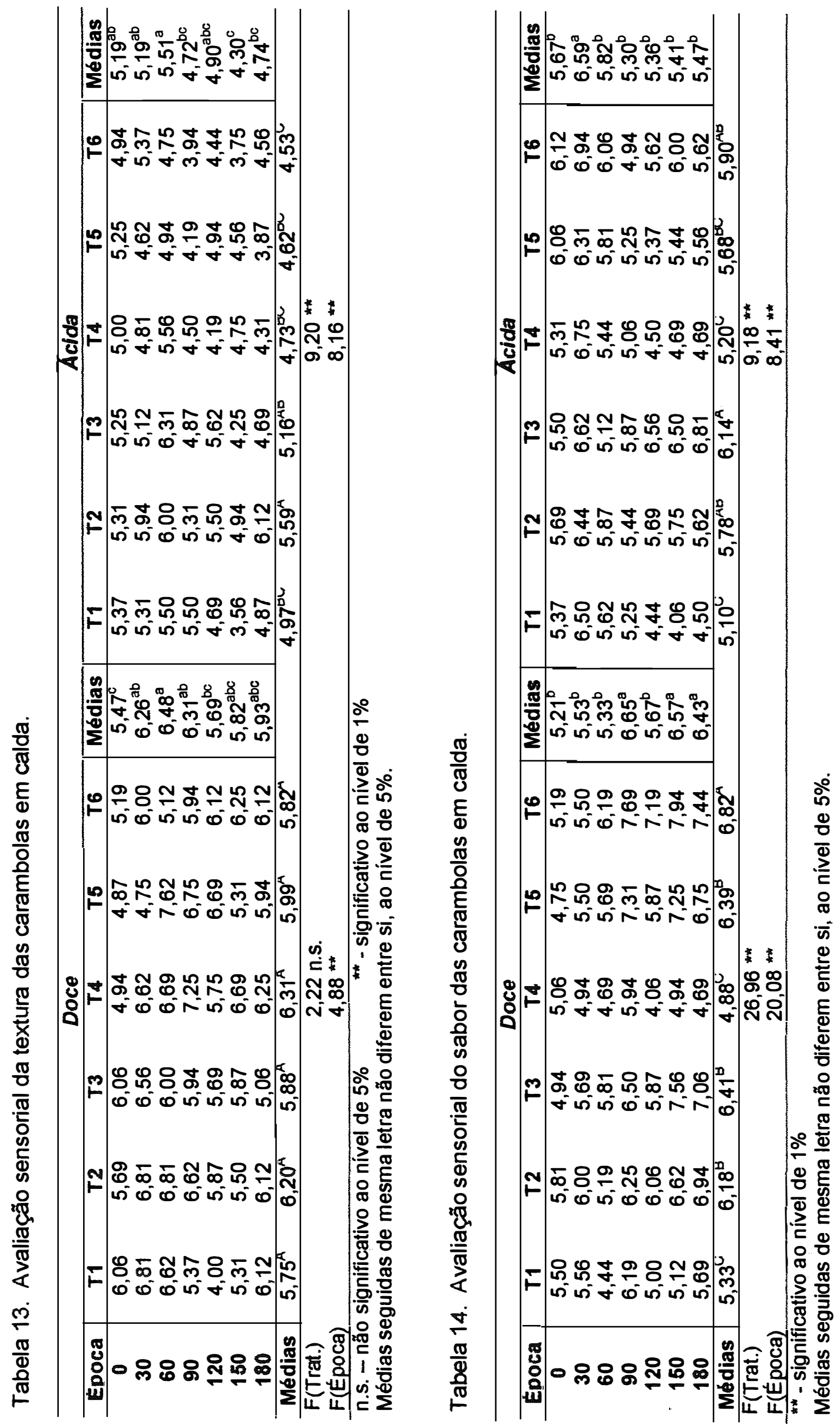
observou-se no tempo zero, e esta diferiu significativamente das demais. O tratamento 1 (fruta + xarope $22^{\circ} \mathrm{Brix}$ ), para as frutas doces, apresentou maior resultado, diferindo dos demais; a menor nota foi observada no tratamento 4 que também diferiu dos outros. Já, para o tipo ácido, as maiores notas foram dos tratamentos 4 (fruta + xarope $22{ }^{\circ} \mathrm{Brix}+0,1 \%$ de $\mathrm{CaCl}_{2}$ ), 5 (fruta + xarope $25^{\circ} \mathrm{Brix}+0,1 \%$ de pectina $+0,2 \%$ de $\mathrm{CaCl}_{2}$ ) e 6 (fruta + xarope $28^{\circ} \mathrm{Brix}+0,2 \%$ de pectina $+0,4 \%$ de $\mathrm{CaCl}_{2}+300 \mathrm{mg}$ de ácido ascórbico/kg de fruta), que não diferiram entre si, mas dos demais. Neste caso, o tratamento 1 apresentou menor nota, e diferiu dos outros.

Pela Tabela 16 e Figura 11 pode-se comparar as médias dos tratamentos dos dois tipos de fruta, em relação às avaliações sensoriais de textura, sabor e cor do produto processado termicamente. Em relação à textura e sabor o tipo doce apresentou maiores notas; no entanto, quanto ao atributo cor foi o tipo ácido que se destacou com notas superiores. Por esta tabela, também poderíamos tirar algumas conclusões: em relação ao tipo doce, não seriam recomendados os tratamentos 1 para o parâmetro textura, e 4 para os parâmetros sabor e cor; em relação ao tipo ácido, não seriam recomendados os tratamentos 6 para textura, e 1 para sabor e cor. 

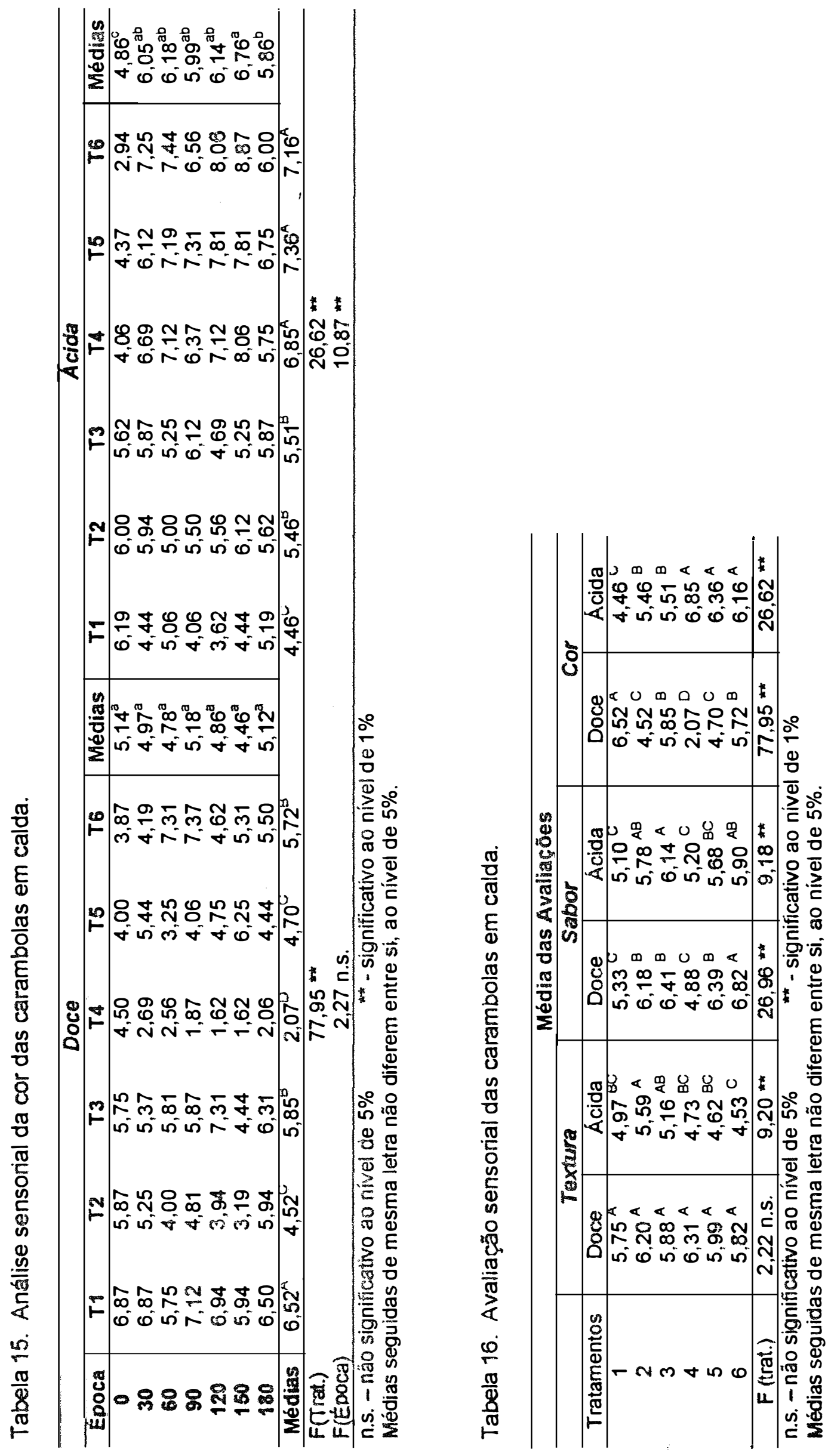


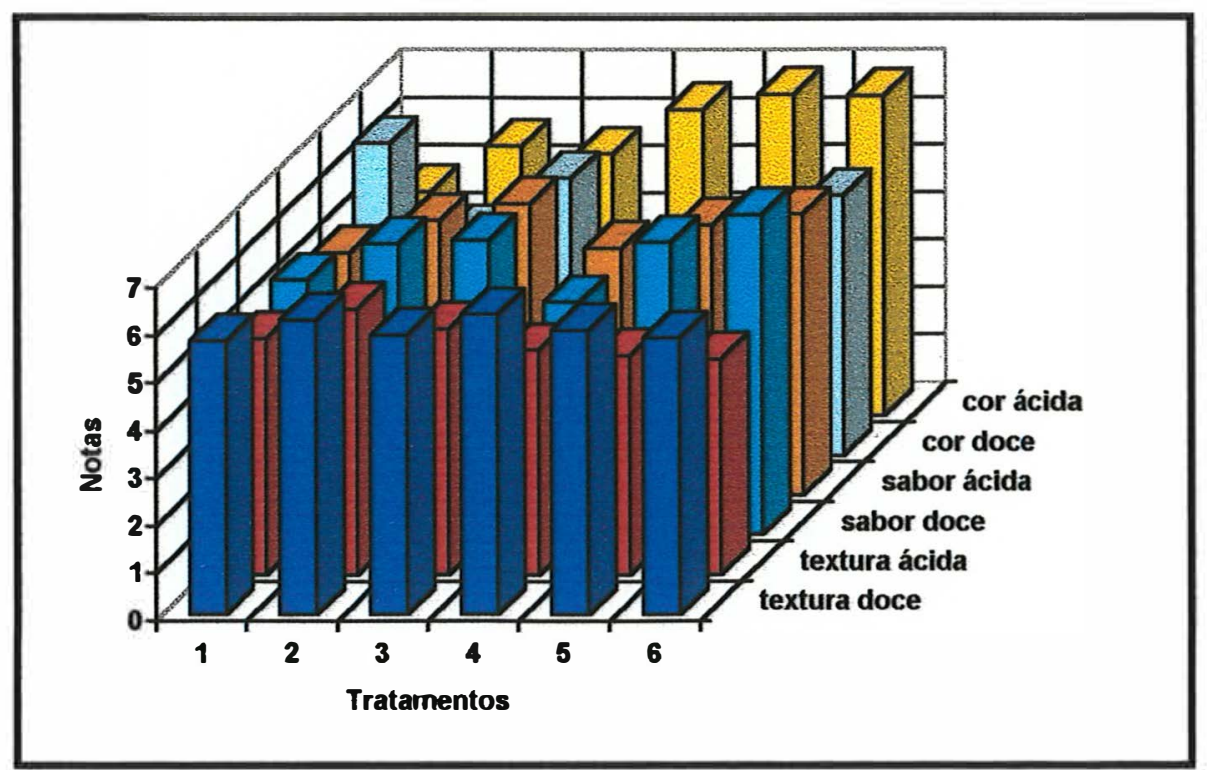

Figura 11. Média das notas das avaliações sensoriais em função dos tratamentos. 


\section{CONCLUSÕES}

Dentro das condiçōes experimentais em que foi realizado este trabalho, pode-se apresentar as seguintes conclusões:

- Sob o ponto de vista tecnológico, os dois tipos de carambola apresentaram boas características físicas (textura e rendimento) e químicas (teor de ácido ascórbico, $\mathrm{pH}$, acidez total titulável e teor de sólidos solúveis).

- É possivel elaborar carambola em calda com os tipos de fruta estudados.

- Em relação à textura, para o tipo doce, o melhor tratamento foi o que empregou fruta, xarope a $28{ }^{\circ} \mathrm{Brix}, 0,2 \%$ de pectina, $0,4 \%$ de $\mathrm{CaCl}_{2}$ e $300 \mathrm{mg}$ de ácido ascórbico/kg de fruta; para o tipo ácido, foi o que empregou fruta, xarope a $25^{\circ}$ Brix e $0,1 \%$ de pectina.

- A adição de $\mathrm{CaCl}_{2}$ não foi efetiva na manutenção da firmeza das frutas ácidas processadas.

- A fruta do tipo doce (tanto processada como "in natura") apresentou melhor textura.

- Até os 90 dias de armazenamento, houve uma melhora na textura, que se estabilizou até o final do armazenamento.

- Para os dois tipos de fruta, como já era esperado, maiores teores de vitamina $C$ foram encontrados nos tratamentos 3 e 6 , devido à adição da mesma ao xarope desses tratamentos. 
- Os teores de ácido ascórbico diminuíram a partir dos 30 dias de estocagem.

- Foi observado que mesmo após 180 dias de armazenamento, os teores de ácido ascórbico foram bastante satisfatórios $(32,91 \mathrm{mg} / 100 \mathrm{~g}$ para o tipo doce, e $36,49 \mathrm{mg} / 100 \mathrm{~g}$ para o tipo ácido).

- O produto processado obtido da fruta ácida apresentou maiores teores de ácido ascórbico.

- Segundo as análises sensoriais o tipo doce apresentou melhor textura e sabor, porém o tipo ácido mostrou-se com melhor cor.

- Para o tipo doce, os melhores tratamentos em relação às análises sensoriais de textura, sabor e cor foram, respectivamente, os que receberam: fruta, xarope a $22{ }^{\circ} \mathrm{Brix}$ e $0,1 \%$ de $\mathrm{CaCl}_{2}$; fruta, xarope a $28^{\circ} \mathrm{Brix}, 0,2 \%$ de pectina, $0,4 \%$ de $\mathrm{CaCl}_{2}$ e $300 \mathrm{mg}$ de ácido ascórbico/kg de fruta; fruta e xarope a $22^{\circ}$ Brix.

- Para o tipo ácido, os melhores tratamentos em relação às análises sensoriais de textura, sabor e cor foram, respectivamente, os que receberam: fruta, xarope a $25^{\circ} \mathrm{Brix}$ e $0,1 \%$ de pectina; fruta, xarope a $28^{\circ} \mathrm{Brix}, 0,2 \%$ de pectina, e $300 \mathrm{mg}$ de ácido ascórbico $/ \mathrm{kg}$ de fruta; fruta, xarope a $25^{\circ}$ Brix, $0,1 \%$ de pectina e $0,2 \%$ de $\mathrm{CaCl}_{2}$.

- Os resultados obtidos neste trabalho sugerem que as carambolas do tipo doce são as mais indicadas para elaboração de fruta em calda; também permitem recomendar a realização de estudos mais detalhados sobre o processamento de carambola em calda, bem como pesquisas sobre outros tipos de conserva para melhor aproveitamento da fruta. 


\section{REFERÊNCIAS BIBLIOGRÁFICAS}

ALMEIDA, M.E.M.; NOGUEIRA, J.N. The control of polyphenol oxidase activity in fruits and vegetables - a study of the interactions between the chemical compounds used and heat treatment. Plant Foods for Human Nutrition, v.47, n.3, p.245-256, April 1995.

ALVEZ, R.M.V.; GARCIA, E.E.C. Embalagem para sucos de frutas. Coletânea do Instituto de Tecnologia de Alimentos, v.23, n.2, p.105-122, jul./dez. 1993.

ANDRADE, M.O.; CAMARGO,R. Tecnologia de alimentos e nutrição. In: CAMARGO, R. Tecnologia dos produtos agropecuários - alimentos. São Paulo: Nobel, 1984. p.9-34.

ARAÜJO, P.S.R.; SCARPARE FILHO, J.A.; MINAMI, K. Carambola: formato e sabor único. Piracicaba: ESALQ, DIBD, 1999. (S

ASSOCIATION OF OFFICIAL ANALYTICAL CHEMISTS - Official methods of analysis. 12.ed. Washington, 1975. 1094p.

AWAD, M. Fisiologia pós-colheita de frutos. São Paulo: Nobel, 1993. 114p.

BALDINI, V.L.S.; DRAETTA, I.S.; NOMURA, E.H. Avaliação bioquímica da carambola (Avernhoa carambola L.). Coletânea do Instituto de Tecnologia de Alimentos, v.12, p.283-291, 1981/1982.

BAUMGARTNER, J.G.; HERSON, A.C. Conservas alimentícias. Zaragoza: Acribia, 1959. cap.9, p.149-180: Princípios del proceso de enlatado de los alimentos. 
BRASIL. Leis, Decretos etc. Ministério da Saúde. Comissão Nacional de Normas e Padrões para alimentos. Resolução $n^{\circ}$ 04/88 do Decreto Lei n.55871/65. In: ASSOCIAÇÃO BRASILEIRA DAS INDÚSTRIAS DE ALIMENTOS. Compêndio da Legislação de Alimentos. rev.4. São Paulo: $A B I A, 1988$. v.1/A, p.3.21, 3.43, 3.48.

CAMPBELL, C.A.; HUBER, D.J.; KOCH, K.E. Postharvest changes in sugars, acids, and color of carambola fruit at various temperatures. Hortscience, v.24, n.3, p.472-475, 1989.

CAMPBELL, C.A.; KOCH, K.E. Acid composition and development of sweet and tart carambola fruit. Journal of American Society of Horticultural Science, v.114, n.3, p.455-457, 1989.

CAMPOS, S.D.S. Textura de alimentos. In: CAMPOS, S.D.S.; GONÇALVES, J.R.; MORI, E.E.M.; GASPARETTO, C.A.; Reologia e textura de alimentos. Campinas: ITAL, 1989. p.12-16.

CARUSO, J.G.B.; CAMARGO, R. Microbiologia de alimentos - generalidades. In: CAMARGO, R. Tecnologia dos produtos agropecuários - alimentos. São Paulo: Nobel, 1984. p.35-49.

CAVALCANTE, P.B. Frutas comestíveis da Amazônia. 3.ed. Belém: INPA, 1976. 116p.

CHEFTEL, J.C.; CHEFTEL, H. Introduccion a la bioquimica y tecnologia de los alimentos. Zaragoza: Acribia, 1988a. v.1, cap.II.4, p.135-213: Los principales sistemas bioquimicos alimentarios - frutas y legumbres.

CHEFTEL, J.C.; CHEFTEL, $H$. Introduccion a la bioquimica y tecnologia de los alimentos. Zaragoza: Acribia, 1988b. v.2. 404p. 
CHESCA, A.C.; FRASSON, C.; PRADO FILHO, L.G. do Estanho em alimentos enlatados. Piracicaba: ESALQ/Departamento de Ciência e Tecnologia Agroindustrial, 1993. 50p.

CHITARRA, M.I.F.; CHITARRA, A.B. Pós-colheita de frutos e hortaliças: fisiologia e manuseio. Lavras: Faepe, 1990. 293p.

CONTI, M. Enzimas pécticas para jugos frutales. La Alimentación Latinoamericana, v.23, n.178, p.35-42, out./nov. 1989.

CRUESS, W.V. Produtos industriais de frutas e hortaliças. São Paulo: Edgard Blücher, 1973. v.1. 446p.

DESROSIER, N.W. The technology of food preservation. 3.ed. Westport: The AVI Publish, 1970a. cap.2, p.27-47: Acceptable food to eat.

DESROSIER, N.W. The technology of food preservation. 3.ed. Westport: The AVI Publish, 1970b. cap.6, p.160-238: Principles of food preservation by canning.

ELEUTÉRIO, R.M.C. Variação do teor de ácido ascórbico e de $\beta$ - caroteno em suco e geléia de acerola (Malpiguia glabra L. - sinônimo M. punicifolia L.) durante o armazenamento. Piracicaba, 1998. 77p. Dissertação (Mestrado) - Escola Superior de Agricultura "Luiz de Queiroz", Universidade de São Paulo.

ESKIN, N.A.M.; HENDERSON, H.M.; TOWNSEND, R.J. Biochemistry of foods. New York: Academic Press, 1971. 240p.

EVANGELISTA, J. Tecnologia de alimentos. 2.ed. Rio de Janeiro: Atheneu, 1992. 652p. 
FERNANDES, M.H.C. Vida de prateleira de enlatados de origem vegetal. Boletim do Instituto de Tecnologia de Alimentos, v.19, n.3, p.227-252, jul./set. 1982.

FONSECA, H. Conservação pelo calor. In: FILHO, A.M.; OLIVEIRA, A.J. de; FONSECA, $H$. et al. Processamento e conservação de alimentos. Piracicaba: ESALQ/Departamento de Ciência e Tecnologia Agroindustrial, 1976. cap. 2.

FONSECA, H.; NOGUEIRA, J.N.; Processamento e conservação de alimentos de origem vegetal - frutas. In: CAMARGO, R. Tecnologia dos produtos agropecuários - alimentos. São Paulo: Nobel, 1984. p.113-124.

GAVA, A.J. Princípios de tecnologia de alimentos. São Paulo: Nobel, 1985. $264 p$.

GOMES, F.P. Curso de estatística experimental. 5.ed. São Paulo: Nobel, 1973. 458p.

GOMES, P. Fruticultura brasileira. 8.ed. São Paulo: Nobel, 1982. 446p.

GRANATO, L. Cultura da caramboleira. Boletim de Agricultura, v.16, n.1, p.486-496, jan. 1915.

HOLDSWORTH, S.D. Conservacion de frutas y hortalizas. Zaragoza: Acribia, 1988. 186p.

IADEROZA, M.; DRAETTA, I.S. Énzimos e pigmentos - influências e alterações durante o processamento. In: SOLER, M.P.; BLEINROTH, E.W.; IADEROZA, M.; DRAETTA, I.S. Industrialização de frutas. 2.ed. Campinas: ITAL/Rede de informação de tecnologia industrial básica, 1991. cap.4, p.17-31. (Manual Técnico, 8). 
JACKIX, M.H. Industrialização de frutas em calda e cristalizadas, geléias e doces em massa. São Paulo: Secretaria da Indústria, Comércio, Ciência e Tecnologia, s.d. cap.2, p.13-71: Frutas em calda.

JOSEPH, J.; MENDONCA, G. Chemical characteristics of Averrhoa carambola

L. Proceedings of Interamerican Society of Tropical Horticulture, n.33, p.111-116, 1989a.

JOSEPH, J.; MENDONCA, G. Studies on the candying process of Averrhoa carambola L. and the utilization of the product in bakery products and desserts. Proceedings of Interamerican Society of Tropical Horticulture, n.33, p.121-126, $1989 \mathrm{~b}$.

KERTESZ, Z.I. The pectic substances. New York: Interscience Publishers, 1951. 628p.

KISS, J. Carambola - pomar de estrelas. Globo Rural, n.150, p.31-34, abr. 1998.

LEME JÚNIOR, J.; MALAVOLTA, E. Determinação fotométrica de ácido ascórbico. Anais da Escola Superior de Agricultura "Luiz de Queiroz", v.7., p.115-129, 1950.

MARTIN, S.L. Selection and training of sensory judges. Food Technology, v.27, n.11, p.22-26, 1973.

MATTHEWS, R.F. Processing of carambola. Proceedings of Interamerican Society of Tropical Horticulture, n.33, p.83-90, 1989.

MATZ, S.A. Food texture. Westport: The AVI Publish, 1962. cap.1, p.3-11: The meaning and importance of texture in foods. 
MENEZES, H.C. Atividade dos ênzimos e sua influência no processamento. In: IADEROZA, M.; BALDINI, V.L.S. Ênzimos e a qualidade de vegetais processados. Campinas: ITAL, 1991. p.11-22. (Manual Técnico)

MONTGOMERY, M.W. Ênzimos importantes no processamento de alimentos. In: IADEROZA, M.; BALDINI, V.L.S. Ênzimos e a qualidade de vegetais processados. Campinas: ITAL, 1991. p.23-36. (Manual Técnico)

MORI, E.E.M. Reologia e textura do ponto de vista organoléptico. In: CAMPOS, S.D.S.; GONÇALVES, J.R.; MORI, E.E.M.; GASPARETTO, C.A.; Reologia e textura de alimentos. Campinas: ITAL, 1989. p.17-42.

NAGY, S.; BARROS, S.; CARTER, R. Production and characterization of carambola essence. Proceedings Florida State Horticultural Science, n.103, p.277-279, 1990.

NOVAES, L.C.C. Avaliação da qualidade dos néctares comum e dietético de morango das variedades Guarani e Oso Grande. Piracicaba, 1997. 119p. Dissertação (Mestrado) - Escola Superior de Agricultura "Luiz de Queiroz", Universidade de São Paulo.

O'CONNOR, T.P.; O'BRIEN, N.M. Significance of lipoxygenase in fruits and vegetables. In: FOX, P.F. (Ed.) Food enzymology. London: Elsevier Applied Science, 1991. cap.8, p.337-372.

OLIVEIRA, M.N. de; MAIA, G.A.; GUEDES, Z.B. de L.; GUIMARÃES, A.C.L.; FIGUEIREDO, R.W. de Características químicas e físico-químicas da carambola (Averrhoa carambola L.). Ciências Agronômicas, v.20, n.1/2, p. 129-133, jul./dez. 1989. 
PASCHOALINO, J.E. Controle das reações catalisadas pelos ênzimos. In: IADEROZA, M.; BALDINI, V.L.S. Énzimos e a qualidade de vegetais processados. Campinas: ITAL, 1991. p.53-58. (Manual Técnico)

PILNIK, W.; VORAGEN, A.G.J. The significance of endogenous and exogenous pectic enzymes in fruit and vegetable processing. In: FOX, P.F. (Ed.) Food enzymology. London: Elsevier Applied Science, 1991. cap.7, p.303336.

PRADO FILHO, L.G. do; PRADO, M.C. Carotenóides - estrutura química, obtenção e emprego em alimentos. Piracicaba: ESALQ/Departamento de Ciência e Tecnologia Agroindustrial, 1992. 42p.

PRESSEY, R. Enzymes involved in fruit softening. In: ORY, R.L.; ANGELO, A.J.St. Enzymes in food and beverage processing. Washington: American Chemical Society, 1977. cap.10, p.172-191. (ACS Symposium Series, 47)

PRUSSIA, S.E.; WOODROOF, J.G. Harvesting, handling and holding fruit. In: WOODROF, J.G.; LUH, B.S. Commercial fruit processing. Westport: The AVI Publish, 1986. Cap.2, p.25-97.

REED, G. Enzymes in food processing. New York: Academic Press, 1966. $483 p$.

RICHARDS, N.S.P.S. Avaliação da qualidade das variedades Chandler e Reiko para a obtenção de morango em calda. Piracicaba, 1996. 90p. Dissertação (Mestrado) - Escola Superior de Agricultura "Luiz de Queiroz", Universidade de São Paulo.

SALES, A.M.; CARVALHO, P.R.N.; IADEROZA, M. et al. Perdas nutricionais em alimentos. Campinas: ITAL, 1988. 105p. (Manual Técnico). 
SALOMÓN, E.A.G.; MARTIN, Z.J.; KATO, K. et al. Formulações de néctares de frutas tropicais. Boletim do Instituto de Tecnologia de Alimentos, n.50, p.103-121, mar./abr. 1977.

SALUNKHE, D.K.; BOLIN, H.R. Developments in technology and nutritive value of dehydrated fruits, vegetables, and their products. In: SANLUNKHE, D.K. (Ed.) Storage, processing, and nutritional quality of fruits and vegetables. Cleveland: CRC Press, 1974. cap.2, p.39-78.

SANT'ANA, H.M.P. Efeito do método de preparo sobre a estabilidade de carotenóides em cenoura. Viçosa, 1995. 115p. Tese (M.S.) Universidade Federal de Viçosa.

SAÚCO, V.G.; MENINI, U.G. La carambola y su cultivo. Roma: FAO, 1991. $96 p$.

SHEWFELT, A.L. Flavor and color of fruits as affected by processing. In: WOODROOF, J.G.; LUH, B.S. Comercial fruit processing. Westport: The AVI Publish, 1975. cap.11, p.497-538.

SILVA, E.; NOGUEIRA, J.N. Efeito do calor na atividade da polifenoloxidase e peroxidase em algumas frutas e hortaliças. Anais da Escola Superior de Agricultura "Luiz de Queiroz", v. 40, n.1, p.137-161, 1983.

SIVIERI, K. Avaliação da qualidade de geléias de morango comum e dietética das variedades Guarani e Oso Grande. Piracicaba, 1997. 124p. Dissertação (Mestrado) - Escola Superior de Agricultura "Luiz de Queiroz", Universidade de São Paulo.

SOLER, M.P.; BLEINROTH, E.W.; IADEROZA, M. et al. Industrialização de frutas. 2.ed. Campinas: ITAL/Rede de informação de tecnologia industrial básica, 1991. 206p. (Manual Técnico, 8) 
STURION, G.L.; MUOZOBA, C.A.; PRADO FILHO, L.G. do Proteinas e vitaminas - alterações causadas pelo processamento térmico de alimentos. Piracicaba: ESALQ/Departamento de Ciência e Tecnologia Agroindustrial, 1991. 55p.

TAPIA-TAPIA, D.M.; PRADO FILHO, L.G. do; RICHARDS, N.S.P.S. Pigmentos naturais e coloração em alimentos. Piracicaba: ESALQ/Departamento de Ciência e Tecnologia Agroindustrial, 1993. 88p.

TAUBER, $H$. The chemistry and technology of enzymes. 2.ed. New York: John Wiley \& Sons, 1949. 550p.

TEIXEIRA, C.G. A industrializaçāo como fator de promoção da agricultura. In: GAVA, A.J. Princípios de tecnologia de alimentos. São Paulo: Nobel, 1985. cap. 1 , p.37-46.

WELLER, A.; SIMS, C.A.; MATTHEWS, R.F. et al. Browning susceptibility and changes in composition during storage of carambola slices. Journal of Food Science, v.62, n.2, p.256-260, March/April 1997. 